\title{
Reach-averaged sediment routing model of a canyon river
}

\author{
S. M. Wiele, ${ }^{1}$ P. R. Wilcock, ${ }^{2}$ and P. E. Grams ${ }^{2}$ \\ Received 20 December 2005; revised 19 May 2006; accepted 26 September 2006; published 22 February 2007.
}

[1] Spatial complexity in channel geometry indicates that accurate prediction of sediment transport requires modeling in at least two dimensions. However, a one-dimensional model may be the only practical or possible alternative, especially for longer river reaches of practical concern in river management or landscape modeling. We have developed a one-dimensional model of the Colorado River through upper Grand Canyon that addresses this problem by reach averaging the channel properties and predicting changes in sand storage using separate source and sink functions coupled to the sand routing model. The model incorporates results from the application of a two-dimensional model of flow, sand transport, and bed evolution, and a new algorithm for setting the near-bed sand boundary condition for sand transported over an exposed bouldery bed. Model predictions were compared to measurements of sand discharge during intermittent tributary inputs and varying discharges controlled by dam releases. The model predictions generally agree well with the timing and magnitude of measured sand discharges but tend to overpredict sand discharge during the early stages of a high release designed to redistribute sand to higher-elevation deposits.

Citation: Wiele, S. M., P. R. Wilcock, and P. E. Grams (2007), Reach-averaged sediment routing model of a canyon river, Water Resour. Res., 43, W02425, doi:10.1029/2005WR004824.

\section{Introduction}

[2] Sediment routing through channels and channel networks presents difficult challenges accounting for local variations in sediment transport and storage. Most sediment storage sites involve spatial variability in erosion and deposition that cannot be captured by a one-dimensional model. These transport fields can be resolved by two- or three-dimensional models, but such models require large amounts of information that are often unavailable, and may be impractical to apply over long distances. An alternative approach developed here is to estimate sediment routing and changes in sediment storage in two separate, coupled calculations. Changes in storage are treated as sources and sinks in the routing formulation and are invisible to the sediment transport calculation, which uses reach-averaged hydraulic geometry. The simplicity of this approach supports testing and interpretation of model components against observation and offers the possibility of application under conditions with sparse data. The approach supports scaling up to larger systems by combining storage components definable at different spatial scales with the finer spatial and temporal discretization needed to describe the downstream movement of sediment.

[3] The primary cost of a reach-averaged approach to sediment routing is that independent relations defining changes in sediment storage must be defined as a function of the geometry of primary sediment storage sites and of the flow and transport computed by the routing model. General

\footnotetext{
${ }^{1}$ U.S. Geological Survey, Tucson, Arizona, USA.

${ }^{2}$ Department of Geography and Environmental Engineering, Johns Hopkins University, Baltimore, Maryland, USA.

This paper is not subject to U.S. copyright.

Published in 2007 by the American Geophysical Union.
}

methods for defining these relations are not currently available. In this paper, we develop a reach-averaged transport model with associated storage functions for the Colorado River in Grand Canyon, a case in which the need for a reach-averaged model is particularly clear. Most of the long-term sediment storage occurs in discrete eddies sheltered from the main flow. No one-dimensional model can capture even the rudiments of transport in these storage sites, although depth-averaged two-dimensional models have been shown to describe the erosion and deposition patterns well [e.g., Wiele et al., 1996]. We used twodimensional transport models of seven characteristic eddy depositional sites to develop sediment scour and deposition functions for a wide range of discharge, sand supply, and initial sand storage conditions. These serve as source and sink functions in the one-dimensional routing model and are combined with the calculated sediment discharge in determining the sediment mass balance at each computational node.

[4] The objective of our one-dimensional sand routing model is to predict the transport and storage of sand for the Colorado River between Glen Canyon Dam and Phantom Ranch (Figure 1). Since closure of Glen Canyon Dam in 1963, the upstream sediment supply to this reach has been reduced by more than 95\% [Topping et al., 2000a, 2000b]. This has resulted in progressive loss of sand storage [Schmidt et al., 2004]. In the postdam environment, eddies associated with debris fans have been observed to be significant sand deposition sites [Howard and Dolan, 1981; Schmidt, 1987, 1990; Webb et al., 1989; Rubin et al., 1990; Schmidt and Graf, 1990; Schmidt and Rubin, 1995]. Hazel et al. [2006] have demonstrated they are the primary sand storage locations since the closure of Glen Canyon Dam. Sand in eddies are important as substrate for flora and fauna, campsites for riverside visitors, and as an 


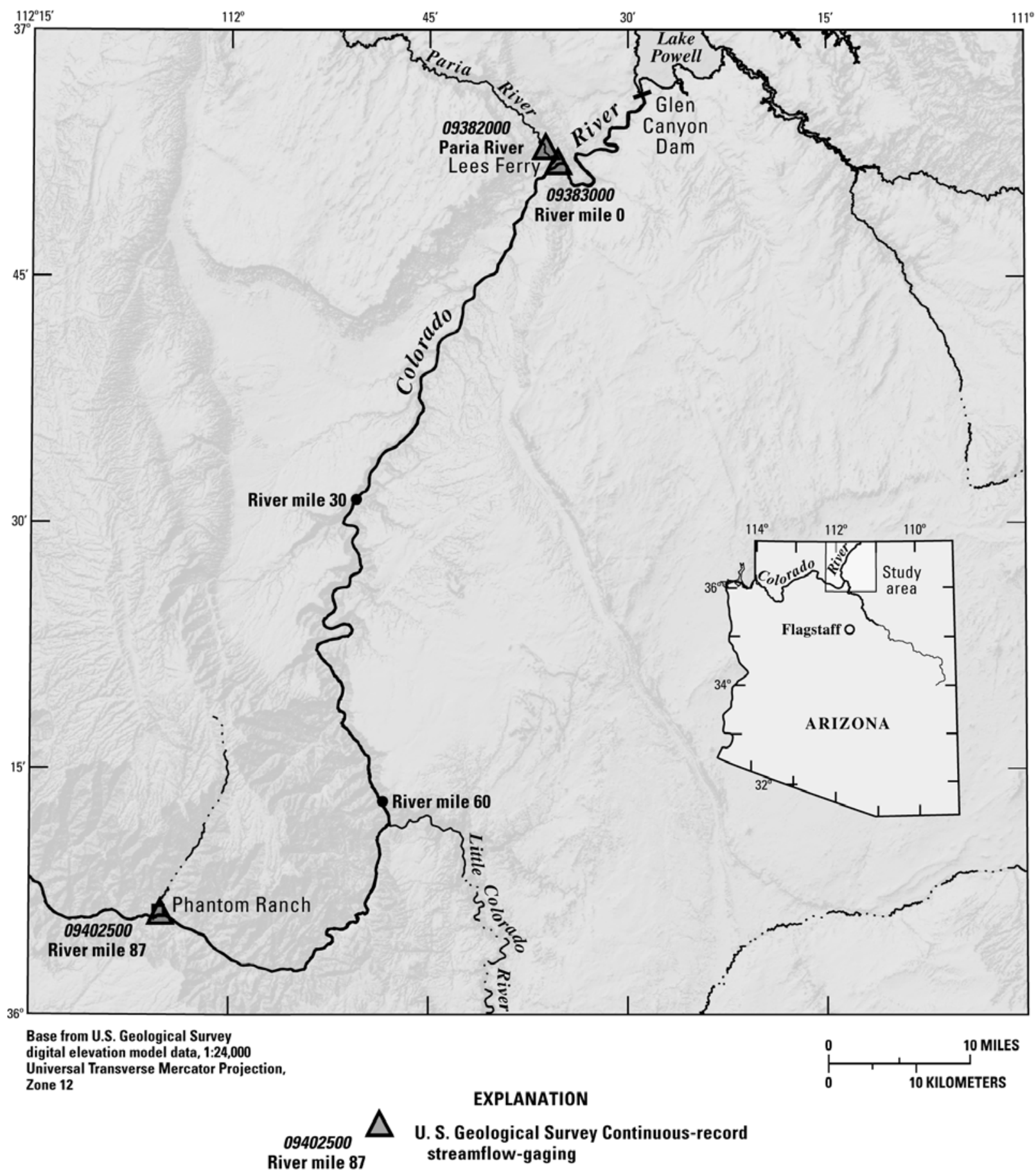

Figure 1. Map of study area. Application of the one-dimensional flow and sand transport model discussed herein start at Lees Ferry (river mile 0) and extended to Phantom Ranch (river mile 87).

esthetic component closely associated with the predam river.

[5] Sand supply to the Grand Canyon is highly variable, with most supply occurring during infrequent floods on the major tributaries. The diminished and variable supply results in highly variable conditions of bed sediment grain size and cover, such that transport rates cannot be calculated with a sediment rating curve [Topping et al., 2000a, 2000b], but must be determined for specified bed conditions using calculations of entrainment rate. Because the riverbed consists of gravel, cobbles, and boulders, the entrainment calculation must be made for a bed with large immobile grains that is partially covered with sand, a condition not well represented by conventional sand transport relations. Hence our model development also required developing a new algorithm for setting the near-bed sand boundary condition for sand transported over an exposed bouldery bed [Grams et al., 2005; Grams, 2006]. 
[6] Randle and Pemberton [1987] modeled the hydraulics and sand transport over long reaches of the Colorado River in Grand Canyon in their pioneering study. Their work was incorporated into an Environmental Impact Statement [U.S. Department of the Interior, 1995] and was the first attempt at a detailed estimate of the sand mass balance of the Colorado River in Grand Canyon. In the past 19 years, however, ongoing data collection and reevaluation of historical data have indicated that the multiyear accumulation of sand on the bed predicted by Randle and Pemberton [1987] has probably not occurred in the postdam period [Topping et al., 2000a]. These recent findings demonstrate the critical importance of the timing of tributary sediment input events relative to the main stem flows on the Colorado River. Thus the relevant timescale for routing sediment in Grand Canyon is the period between the onset of tributary sediment supply events and the occurrence of main stem flows that redistribute that sediment.

[7] On the basis of these recent findings, management of the river corridor has focused on rebuilding eddy sandbars by using high flow releases from Glen Canyon Dam following significant inputs of sediment from the Paria River, the primary sediment source upstream from the first $120 \mathrm{~km}$ below Glen Canyon Dam [U.S. Department of the Interior, 2002, 2004]. The first such timed release occurred in November 2004. We developed the model presented here in order to evaluate the response of main stem transport to tributary inputs and variations in discharge.

\section{Model Components}

\subsection{Model of Unsteady Flow}

[8] Unsteady flow is calculated with a reach-averaged diffusion wave model [Wiele and Griffin, 1997; Wiele and Smith, 1996]. Channel shape was determined from cross sections measured at about $1.6 \mathrm{~km}$ intervals that were averaged to form a characteristic cross section. Computational nodes are about $1 / 2 \mathrm{~km}$ apart. Wiele and Griffin [1997] inferred the hydraulic geometry from hydrographs measured during the falling limb of an experimental release in 1996. During that event, discharge was lowered at Glen Canyon Dam from $1274 \mathrm{~m}^{3} / \mathrm{s}$ to $226 \mathrm{~m}^{3} / \mathrm{s}$ over 46 hours. Discharge at the dam fell at a nearly constant rate, so the change in waveshape was well represented as a kinematic wave in which the wave speed as a function of discharge is $d Q / d A$, where $Q$ is discharge and $A$ is cross-sectional area. The wave speed, and thus $d Q / d A$, as a function of discharge was determined from the streamflow-gauging stations at Lees Ferry (river mile 0) (Figure 1) and Diamond Creek (river mile 225). (River miles (RM) are designated with respect to Lees Ferry, 15 river miles below Glen Canyon Dam, and are typically used to indicate location along the river; we use the river mile designation of Breedlove and Mietz [2002]). Integration of a function fit to $d Q / d A$ as a function of discharge by using a dye study at $425 \mathrm{~m}^{3} / \mathrm{s}$ [Graf, 1995] to provide the constant of integration yielded the hydraulic geometry used in the diffusion wave equation. The model showed good agreement with data from gauging stations located at RM 62, 87, 166, and 225 [Wiele and Griffin, 1997].

\subsection{Main Stem Suspended Sand Transport}

[9] Suspended sand transport at each node is first calculated with the Rouse [1937] suspended sand concentration profile:

$$
\frac{c}{c_{a}}=\left(\frac{z_{a}(h-z)}{z\left(h-z_{a}\right)}\right)^{P}
$$

where $c$ is sand concentration, $c_{a}$ is the reference sand concentration, $z$ is the vertical dimension above the bed, $z_{a}$ is the distance above the bed where $c=c a, P=w_{s i} / \kappa u_{*}, w_{s i}$ is the settling velocity for particles in the $i$ th size range, $\kappa$ is von Karmann's constant $(0.4)$ and $u *$ is the shear velocity.

[10] The product of the velocity and the suspended sand concentration is then integrated to determine the local transport if sufficient sand is on the bed. If the sand volume on the bed between nodes is less then the transport calculated with the velocity and sand concentration profiles over a time step, then sand mass is conserved by resetting the sand transport to the sand volume on the bed divided by the time step.

[11] A critical component of solving the Rouse profile is the determination of the near-bed sand concentration, $c_{a}$, used for the lower sand boundary condition. Because sand in Grand Canyon is typically transported over a bed composed of meter-scale boulders rather than a sandcovered bed, conventional relations that yield a sand concentration at a given distance above the bed cannot be used without modification. Grams et al. [2005] studied suspended sand transport in a flume under conditions similar to those characteristic of the Colorado River in Grand Canyon. They developed a correction, $g_{w}$, that accounts for the difference between near-bed sand concentration over a bed with large exposed roughness and near-bed sand concentration over a sand bed:

$$
g_{w}=\left[1+\exp \left(-k\left(z^{*}-z_{g w}\right)\right)\right]^{-1 / 2},
$$

where, $z^{*}=z / d_{b}$ and $d_{b}$ is the characteristic size of coarse bed material. The coefficients $k$ and $z_{g w}$ are set by analysis of flume experiments [Grams et al., 2005] and have values of 12 and 0.65 , respectively. The near bed sand concentration predicted in the absence of boulders is multiplied by $g_{w}$. They found that the algorithm for near-bed sand concentration of Garcia and Parker [1991] provided the best fit with their flume data.

$$
\begin{gathered}
Z_{m i}=\frac{u *_{s f}}{w_{s i}} R_{p i}^{0.6}\left(\frac{d_{i}}{d_{50}}\right)^{m}, \\
E_{s i}=\frac{A\left(\lambda Z_{m i}\right)^{5}}{1+\frac{A}{0.3}\left(\lambda Z_{m i}\right)^{5}},
\end{gathered}
$$

where $u *_{s f}$ is the skin friction shear velocity, $m$ is an exponent representing mixed grain size effects, $R_{p i}=\left[\left(\rho_{s}-\right.\right.$ $\left.\rho) G D_{I}\right]^{1 / 2} / \nu, \rho_{s}$ is the sediment density, $\rho$ is water density, $g$ is gravitational acceleration, $d_{i}$ is the grain size 
representative of the $i$ th class, $\nu$ is kinematic viscosity, $d_{50}$ is the median grain size, $E_{s i}$ is the nondimensional entrainment rate, $\lambda$ is a coefficient representing mixed grain size effects, approximated by $1-0.288 \sigma_{\phi}, \sigma_{\phi}$ is the standard deviation of the grain mixture on a $\phi$ scale, and $A=$ $1.3 \times 10^{-7}$. The near-bed sand concentration used as a lower boundary condition in the sand concentration calculation is determined from $c_{a}=g_{w} E_{s i}$.

[12] Grain stress used in (4) was determined with an Einstein decomposition [Einstein, 1950] using a power law approximation of the logarithmic profile [van Rijn, 1984]:

$$
\frac{u}{\sqrt{g h_{s f} S}}=8.32\left(\frac{h_{s f}}{k_{s}}\right)^{1 / 6} \text {, }
$$

where $S$ is the water surface slope, $u$ is flow velocity, $h_{s f}$ is the skin friction depth, and $k_{s}=3 d_{90}$.

[13] Size of bed material is not used in the calculation of grain stress, but plays a role in (2) and calculation of the volume of sand stored on the bed. In cooperation with the Grand Canyon Monitoring and Research Center (GCMRC), we deployed an underwater video camera to look at the channel bottom at about 200 locations in July 2003. The camera was equipped with parallel lasers that projected beams $10 \mathrm{~cm}$ apart. These beams enabled the estimation of the size of material on the bed. The dominant coarse bed material fraction was estimated from 73 video clips taken between Lees Ferry and Phantom Ranch. Thirty-two percent of the images were in the cobble-boulder size classes (64$256 \mathrm{~mm}$ and $>256 \mathrm{~mm}$ ) and $55 \%$ were in the coarse gravelcobble sizes classes (32-64 $\mathrm{mm}$ and 64-256 mm). Twentythree percent were in the sand size class; sand covered beds typically had a dune bed configuration with dune height of order $30-75 \mathrm{~cm}$, forming a roughness height comparable to the cobble-boulder bed. Regions with very large grains (e.g., rockfall and debris fan rubble) were not imaged to avoid excessive risk to equipment. This analysis indicates the characteristic roughness is of the order of $1 \mathrm{~m}$, and we used $1 \mathrm{~m}$ in the model.

[14] Bed load is not included in the sand transport calculations. Order-of-magnitude comparisons of calculated bed load and suspended load demonstrate that bed load is negligible compared to suspended load.

[15] The change in sand volume over a time step is calculated with a finite difference form of the sediment continuity equation,

$$
\delta v_{i}=-c_{b} \delta Q_{s i} \delta t
$$

where $\delta v_{i}$ is the change in volume of the $i$ th fraction of bed sand between computational nodes, $c_{b}$ is the concentration of bed sediment, $\delta Q_{s i}$ is the is the difference in the discharge of the $i$ th sand fraction between computational nodes, and $\delta t$ is the time step. Equation (6) is solved numerically with the Crank-Nicholson scheme [Anderson et al., 1984].

[16] Sand is organized on the bed into an upper active layer, an intermediate mixed layer, and a lower undisturbed layer, following the method of Bennett and Nordin [1977]. Examination of the flume deposits in the experiments used to develop (2) revealed that over timescales of about an hour, the mixing depth was on the order of the roughness elements, and that result is used in our model.
[17] Application of modeling results to assess main stem transport responses to changes in discharge or sand supply requires a characterization of reach-averaged hydraulic geometry. Schmidt and Graf [1990] used bedrock type near water level as a guide in dividing the channel into geomorphically similar reaches: RM-15 (the location of Glen Canyon Dam) to RM 0 (Lees Ferry), then bounded at RM 11, 25, 42, 66, 77, and 87. Melis [1997] used debris fan characteristics to determine similar geomorphic reaches that had similar boundaries. We used the boundaries of Schmidt and Graf [1990] with one exception. We combined two reaches between river miles 42 and 77 into one reach because they were hydraulically similar. Geographic information systems (GIS) coverages based on a 1-m digital elevation model of the river corridor topography have been developed that include the $160 \mathrm{~km}$ of the study area that extends from Glen Canyon Dam to Phantom Ranch (M. Breedlove, Grand Canyon Monitoring and Research Center, written communication, 2003). This coverage, however, does not extend below the $226 \mathrm{~m}^{3} / \mathrm{s}$ water surface elevation. The lower limit of the channel shape defined by the $226 \mathrm{~m}^{3} / \mathrm{s}$ water surface elevation was determined by the water surface elevation at the time the aerial photos of the channel were taken. The $2745 \mathrm{~m}^{3} / \mathrm{s}$ water surface elevation was estimated by Wright et al. [2003] from the results of Randle and Pemberton [1987]. For computing reach-averaged channel shapes for the seven reaches, channel cross sections were extracted every $80 \mathrm{~m}$ (M. Breedlove, Grand Canyon Monitoring and Research Center, written communication, 2003) to elevations higher than the $2745 \mathrm{~m}^{3} / \mathrm{s}$ water surface elevation. The $80 \mathrm{~m}$ spacing yielded a sampling density Griffin [1997] found to be optimal for representing average channel shapes in her study of reach-averaged channel shape in the Grand Canyon.

[18] The channel shape above the $226 \mathrm{~m}^{3} / \mathrm{s}$ water surface elevation was averaged in each of the seven reaches by using a method similar to that of Griffin [1997]. The cross channel distances on the left and right sides of the channel were normalized by the channel width between the 226 and $2745 \mathrm{~m}^{3} / \mathrm{s}$ water surface elevations. The cross-distancenormalized channel shapes were then averaged.

[19] The only complete, quasi-randomly sampled surveys of the channel bottom are those of Wilson [1986], who surveyed channel cross sections with a fathometer at $1.6-\mathrm{km}$ intervals at about $849 \mathrm{~m}^{3} / \mathrm{s}$. We averaged the Wilson cross sections to extend the channel shape below the $226 \mathrm{~m}^{3} / \mathrm{s}$ water surface. The upper and lower channel shape were matched at the $425 \mathrm{~m}^{3} / \mathrm{s}$ water surface elevation because the reach-averaged cross-sectional area at $425 \mathrm{~m}^{3} / \mathrm{s}$ could be derived from reach-averaged velocities determined from a dye study [Graf, 1995] at that discharge (Figure 2).

[20] The channel resistance for each of the seven reaches was determined by using the stage-normalized curve of Wiele and Torizzo [2003], who found that normalized stagedischarge curves had similar shapes despite widely varying stage ranges over the same discharge range at the gage sites. Griffin and Wiele [1997] used a similar method to derive reach-averaged channel hydraulic geometry, and found that it produced predictions of unsteady flow similar to a largerscale reach-averaged one-dimensional model of unsteady flow [Wiele and Griffin, 1997] when applied to reachaveraged channel shapes. The stage-normalized curve rep- 


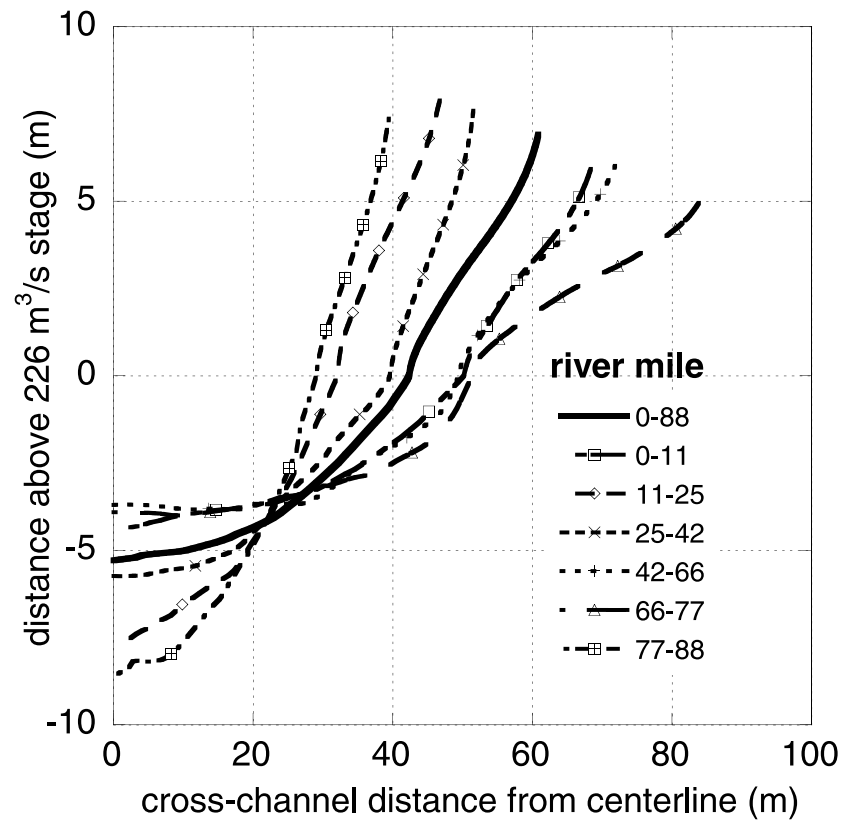

Figure 2. Average channel shape for the seven averaged reaches.

resents a general relation between stage and discharge. Dimension is restored to the stage by using the difference in stage at two known discharges. The reach-averaged stages at $226 \mathrm{~m}^{3} / \mathrm{s}$ and $2745 \mathrm{~m}^{3} / \mathrm{s}$ were used to restore the stage dimension for the seven averaged reaches (Figure 3 ).

\subsection{Pools}

[21] Reach-averaged hydraulic geometry does not directly account for deep pools that can temporarily store sand in

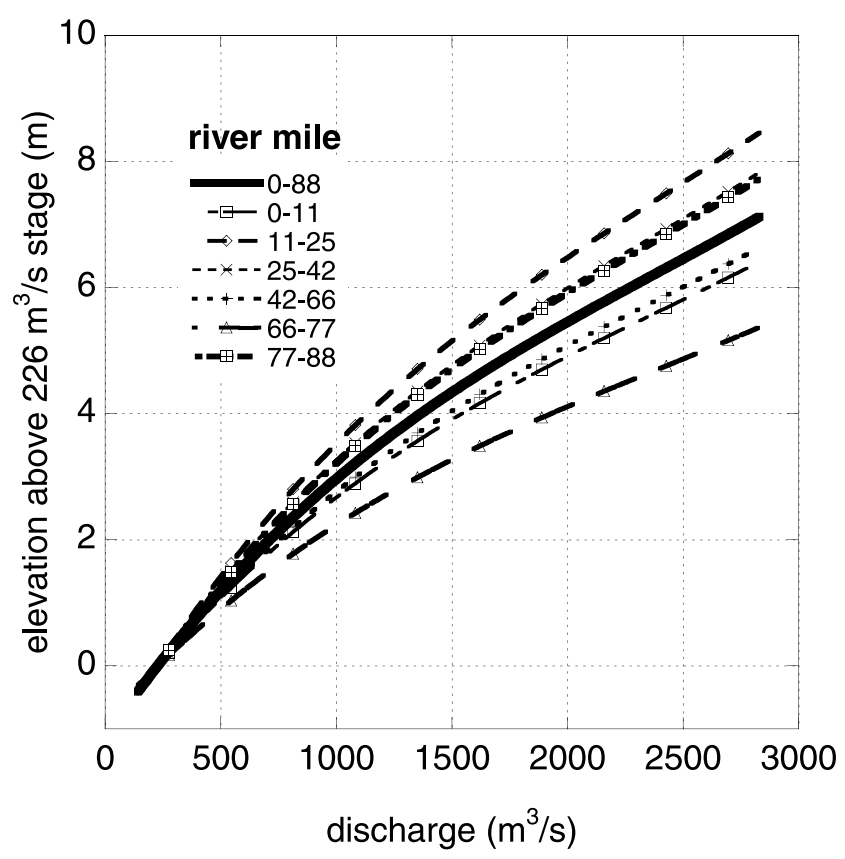

Figure 3. Stage-discharge relations derived from the stage-normalized curve and the difference between water surface elevations at 226 and $2745 \mathrm{~m}^{3} / \mathrm{s}$ for the seven averaged reaches.

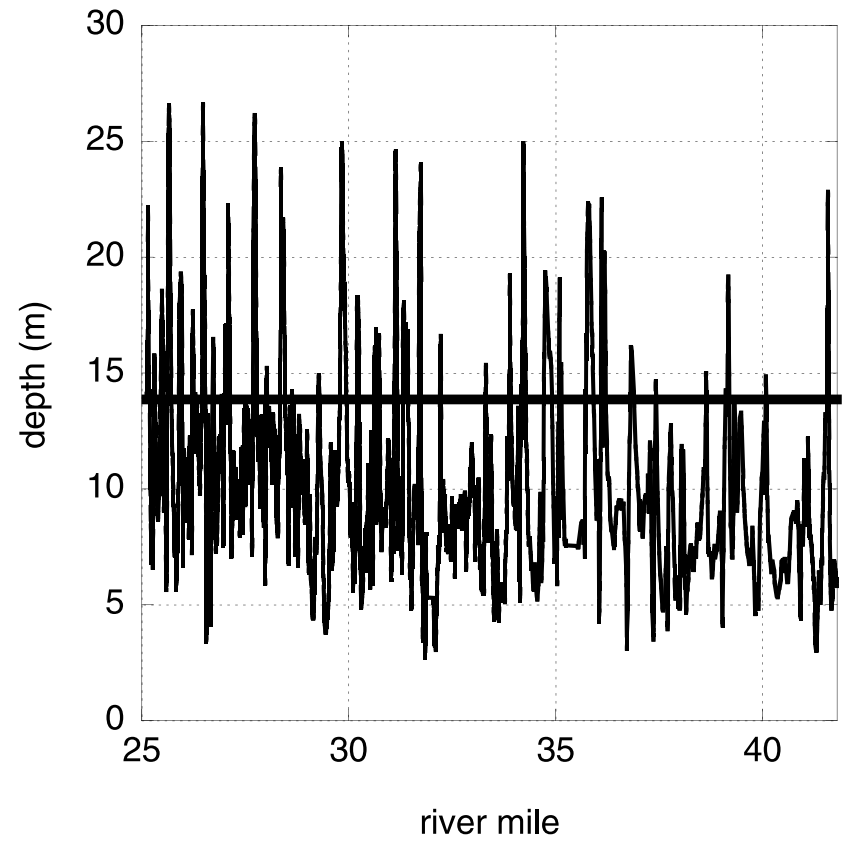

Figure 4. Depth from the 1984 channel bottom trace [Randle and Pemberton, 1987] over part of the modeling study reach. One standard deviation greater than the average depth is shown with a solid horizontal line. Depths greater than that line were considered to be pools.

transit, especially at low flow. Pools can be accounted for in two ways: increase storage in the hydraulic geometry or add pools at discrete locations along the reach-averaged channels. Because pools are part of the main flow, they can be added directly to the calculation of flow and sand transport, unlike the channel-side environments, if data are available to estimate the size, depth, and locations of the pools. Complete bathymetry of the Colorado River between Glen Canyon Dam and Phantom Ranch has not been measured, but continuous traces of the channel bottom have been recorded in 1965 [Leopold, 1969] and in 1984 [Randle and Pemberton, 1987]). We used these traces to estimate pool characteristics and add them to the downstream routing of sand.

[22] The magnitude of the deviations of bed elevation from the average channel bed are not symmetrical (Figure 4). Deviations from the average depth are larger at depths greater than average than at those smaller than average. The standard deviations of the shallower and deeper depths computed separately with respect to the average depth show the deeper depths have greater variability and larger deviations than the shallower depths. We determined the pool characteristics from the channel traces by locating the largest deviations from the average channel shape.

[23] The 1984 trace has an order of magnitude greater resolution than the 1965 trace and was used between river miles 7 and 88. The 1965 trace was used for the first seven river miles. Both traces were recorded from river rafts, and although the precise location of the measurements is not known, rafts typically travel near midstream and so the traces are a reasonable representation of channel thalweg elevation for this application. 


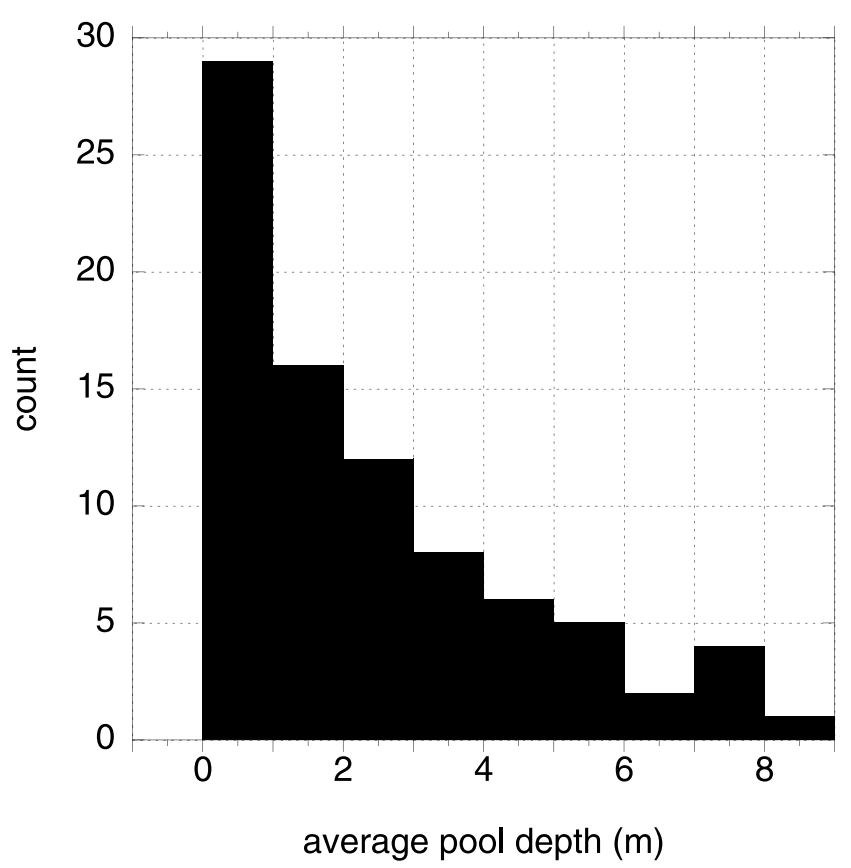

Figure 5. Distribution of pool depths for the reach shown in Figure 4.

[24] For each average reach, the average depth was first calculated and standard deviations of depths less than and greater than the average were computed (Figure 4). The depths were then filtered by eliminating depths smaller than a fixed number, and the average depth and standard deviations were recomputed. The filtering depth was adjusted until the standard deviation of the depths less than and greater than average were equal. We considered parts of the channel greater than the filtering depth to be pools. These pools were added to the spatially averaged reaches, and pools smaller than the grid spacing were combined into single pools. The distribution of pool depths for one of the hydraulically similar model reaches is shown in Figure 5, and the distribution of lengths is shown in Figure 6.

\subsection{Scour and Deposition in Eddies}

[25] In developing the sand source and sink terms, we modeled eddy scour (a sand source to the routing model) associated with changes in discharge as a relatively rapid response to the expansion of the downstream current under conditions of increasing water discharge. Lateral expansion of the downstream current during increasing discharge exposes sand deposits sheltered by debris fans at lower flows to higher near-bed velocities and thus facilitates entrainment of sand in these deposits. In contrast, eddy deposition (a sand sink for the routing model) occurs more continuously over time in response to the sand delivered from the main flow to the eddy. The time dependence of eddy deposition and the rapid scour of lower eddy deposits associated with increased discharge have been demonstrated by previous model applications [e.g., Wiele and Torizzo, 2005] and surveys repeated during depositional events [Andrews et al., 1999]. Thus eddy scour is calculated as a function of change in discharge, whereas eddy deposition is calculated by using a deposition rate over time. Scour and deposition are calculated separately and occur simulta- neously at different parts of the eddy. For both functions, application in the routing model requires accounting for the volume of sand stored in the eddy at any moment, as well as the characteristic eddy geometry associated with each modeling reach. The source and sink submodels were developed as functions of water and sediment discharge (calculated in the model), proportion of eddy fill (tracked in the model), and average eddy geometry (determined from survey and mapping data for each modeling reach by Schmidt et al. [2004]).

[26] A two-dimensional model of flow, sand transport, and changes in sand deposits has been used in Grand Canyon to examine the effects of a major tributary flow on downstream sand deposits [Wiele et al., 1996], to compare the effects of dam releases and tributary flooding on sand deposition rates and locations [Wiele, 1997; Wiele et al., 1999], and to evaluate the effect of dam operation and sand supply on sand deposits in archeologically sensitive areas [Wiele and Torizzo, 2005]. The model predictions of sand deposition in eddies have shown good agreement with changes in cross sections measured before and after tributary flooding [Wiele et al., 1996] and with surveys of bed changes during a high dam release [Wiele et al., 1999]. For this study, the two-dimensional model was applied to seven reaches over a range of flow and transport conditions to provide a basis for estimating exchange between the main stem transport and the eddies (Figure 7).

[27] The sink term represents the accumulation of sand in the eddy that is lost to main stem transport. This sand is primarily deposited deep in the eddy during high flows and is generally removed from the main stemflow. Significant amounts of sand can be delivered to the main stem over long periods via slow erosion from the eddies. We do not attempt to capture this process here.

[28] Previous applications of the two-dimensional model have shown the time-dependant nature of sand deposition in the eddies. In general, deposition after a significant increase

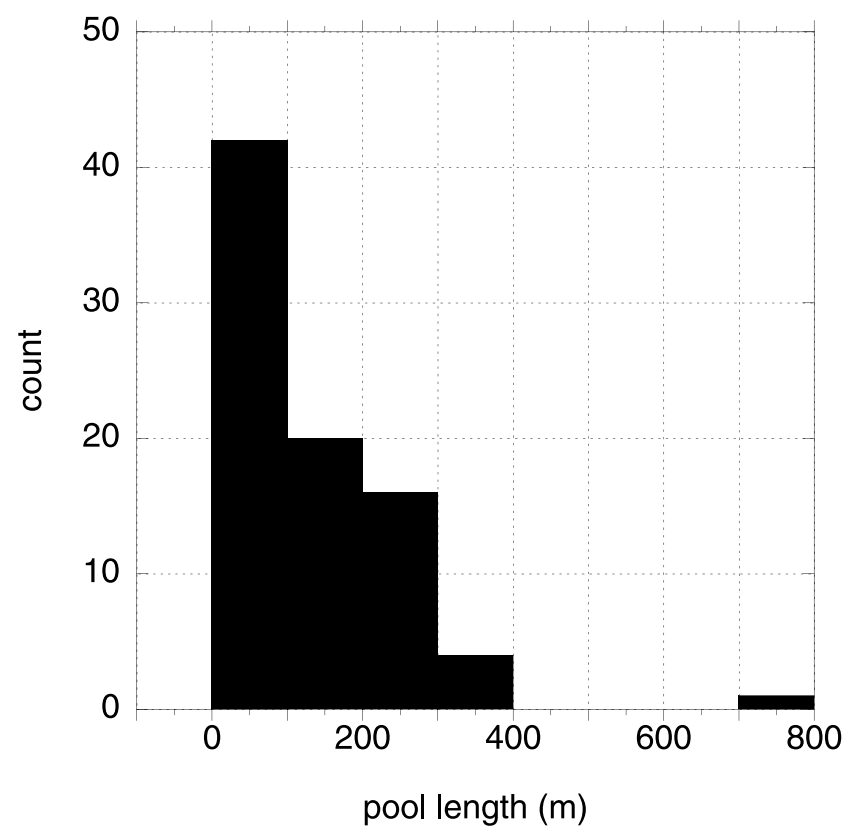

Figure 6. Distribution of pool lengths for the reach shown in Figure 4. 


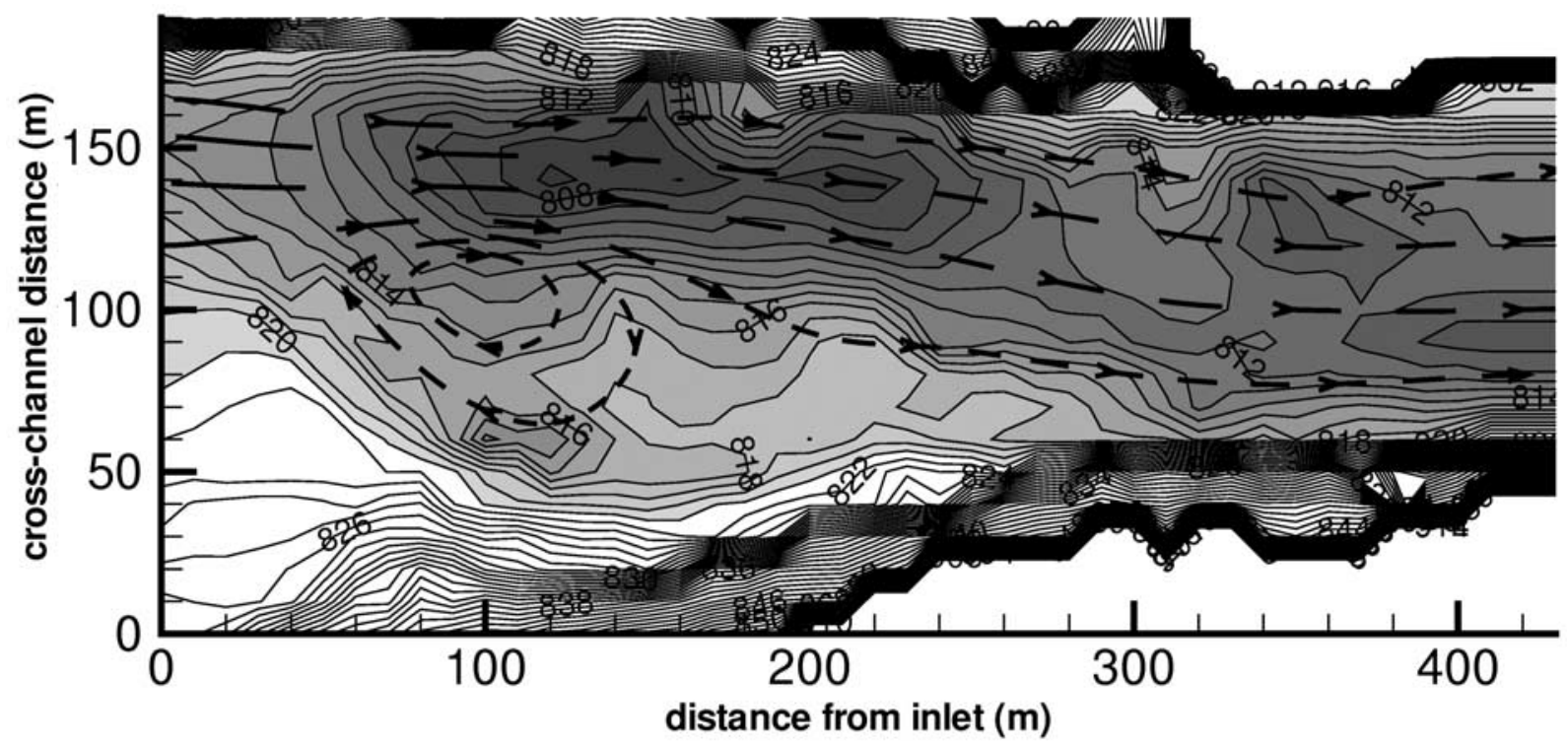

Figure 7. Map of the two-dimensional modeling site at river mile 65. Dashes in the computed flow lines represent water movement over $10 \mathrm{~s}$. The contour interval is $1 \mathrm{~m}$.

in discharge, such as occurred during the 1996 and 2004 releases, is initially very fast, and asymptotically approaches a maximum value, representing a full eddy, over several days. Past two-dimensional model applications [e.g., Wiele, 1997] have shown that eddy deposition rates typically increase with increasing discharge and sand supply. The volume in the full eddy varies with water and sand discharge and is generally positively correlated with both. Consequently, the sink term must account for the variation over time and is in the form of $d v / d t$; it can be scaled by the volume of sand in a full eddy.

[29] The source term represents sand that is entrained from channel-side deposits by main stemflow as discharge increases. In the simplest form of a one-dimensional model, this term could be accounted for as a user-specified parameter, based on surveys, user experience, or as part of an analysis of the sensitivity of the results to source placement and volumes. This approach would be consistent with events such as the 1996 release, which occurred long after significant tributary inputs, and during which the system was in a stable, albeit steadily declining, condition. The November 2004 release followed heavy tributary inputs by only about 2 months during which the flow was kept low in an effort to retain sand in the upper reaches of Marble Canyon. Consequently, the system was in a transient state, and under these conditions a more complete model capable of mimicking the interaction of main stem transport and potential source volumes is needed.

[30] Eddies have been shown to lose sediment over time [Schmidt et al., 2004] usually at a slow rate during normal dam operation. Sudden losses due to apparent slumping have also been documented [Cluer, 1995]. For significant increases in discharge, the primary mechanism for eddy scour is the widening of the main stemflow as the eddyforming debris fan is inundated [Melis, 1997] and eddy deposits are exposed to the brunt of main stem current. If discharge is steady, lower eddy deposits are not subject to scour beyond the ongoing slow entrainment that contributes to eddy deposit decline. If discharge declines, then the flow narrows and additional space sheltered by the debris fan is created and the lower eddy deposits can potentially increase. Because the lower eddy deposits are close to the main stem current and are small compared to total eddy volume, the source volume response to variations in discharge is taken in the model to be instantaneous. This approach significantly enhances the tractability of the source algorithm. Thus the source term has the form $d v / d q$.

\subsubsection{Scour From Eddies}

[31] The two-dimensional model was applied to the seven two-dimensional modeling reaches at discharges ranging from $283 \mathrm{~m}^{3} / \mathrm{s}$ to $2830 \mathrm{~m}^{3} / \mathrm{s}$. In order to capture the effect of discharge variation on eddy erosion consistent with our conceptual model of eddy scour, after an initial constant discharge for 3 hours at $283 \mathrm{~m}^{3} / \mathrm{s}$, the discharge was increased at a rate of $57 \mathrm{~m}^{3} / \mathrm{s} / \mathrm{hr}$ to $2830 \mathrm{~m}^{3} / \mathrm{s}$. The initial eddy sand bed was taken from modeling results used to derive the eddy deposition algorithm. Results from the twodimensional model were used to fit a series of functions from which scour over a time step is computed.

[32] In the following steps, scour of sand from the eddies is represented by a series of functions derived from the twodimensional model. We first compute a reference scour volume that depends on the change in discharge (steps 1 and 2). Steps 3 and 4 compute a reference eddy volume that corresponds to the reference scour volume in the twodimensional model applications. The scour volume at a node is then computed as a function of the reference scour volume scaled by the ratio of the eddy volume at that node to the reference eddy volume. The steps used to compute scour at a node are:

[33] 1. A nondimensional reference scour volume as a function of the change in discharge is calculated at each node using the derivative of the fitted line in Figure 8. The discharge of $1274 \mathrm{~m}^{3} / \mathrm{s}$ was chosen as the reference discharge because it is close to the two high-discharge experimental releases $\left(1274 \mathrm{~m}^{3} / \mathrm{s}\right.$ in 1996 and $1187 \mathrm{~m}^{3} / \mathrm{s}$ in 2004). 


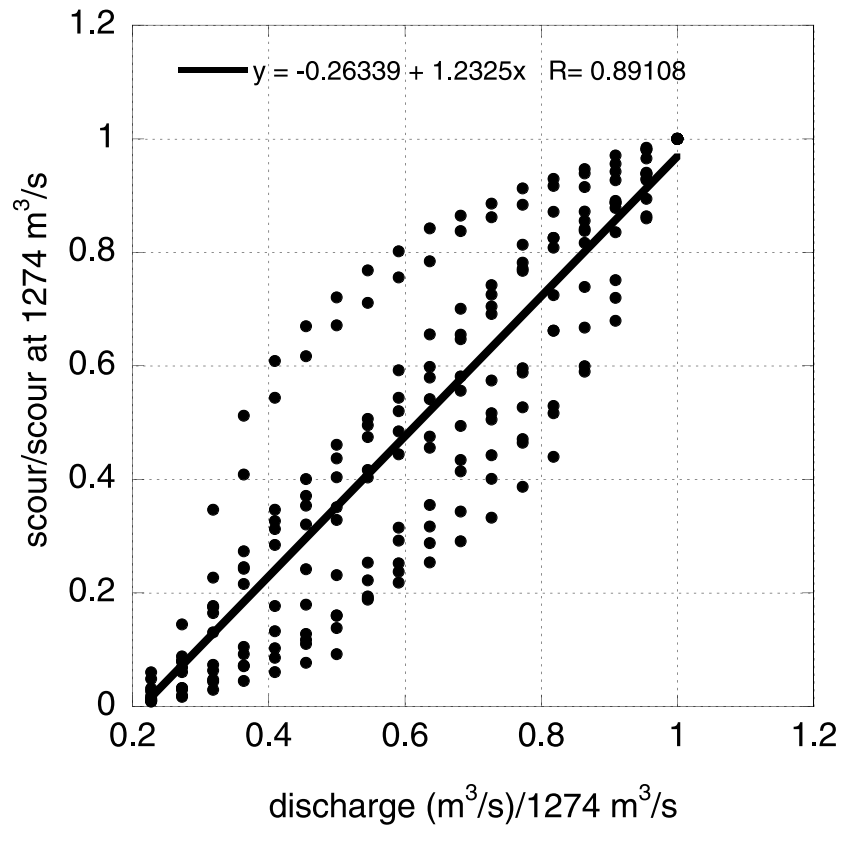

Figure 8. Model-predicted nondimensional total eddy scour as a function of discharge normalized by $1274 \mathrm{~m}^{3} / \mathrm{s}$.

[34] 2. A dimension for the reference scour volume at $1274 \mathrm{~m}^{3} / \mathrm{s}$ is calculated (Figure 9) by using a function that relates the reference scour volume to increase in stage above $84.9 \mathrm{~m}^{3} / \mathrm{s}(\delta z)$ and to eddy characteristics: $S_{f}$, slope of the upstream debris fan; $A_{e}$, eddy area; and $P$, the eddy perimeter. These eddy and debris fan characteristics have been measured at representative sites or are shown on maps throughout the study area [Melis et al., 1994; Breedlove and Mietz, 2002; Schmidt et al., 2004; J. Hazel, Northern Arizona University, written communication, 2002] and are likely related to the eddy sand storage potential. Hydraulic

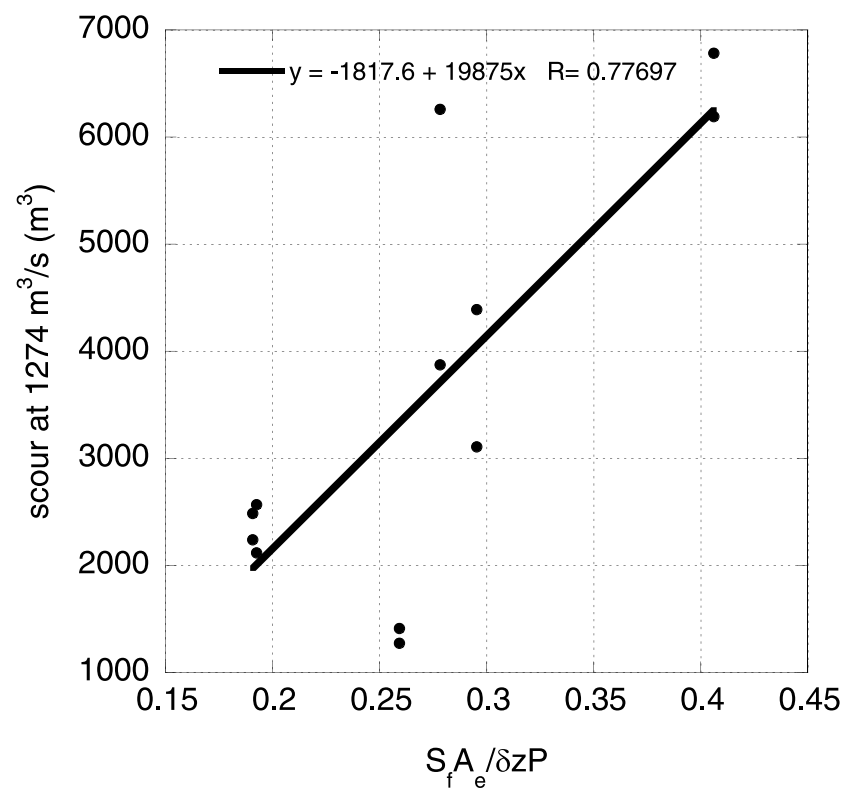

Figure 9. Model-predicted total scour at $1274 \mathrm{~m}^{3} / \mathrm{s}$ as a function of eddy characteristics.

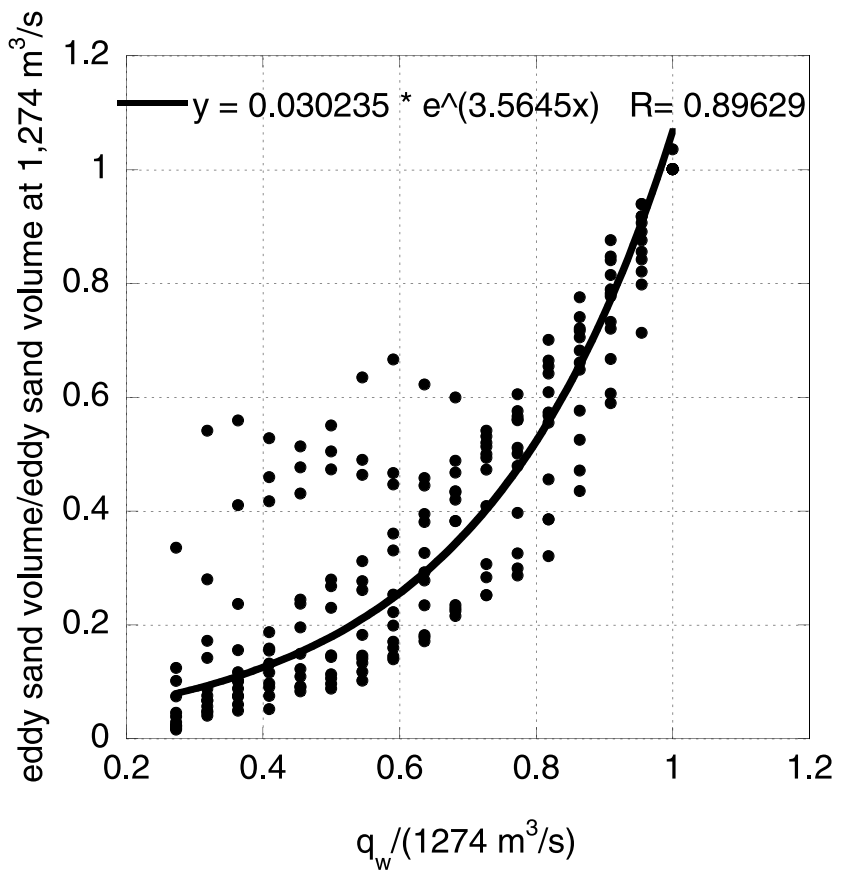

Figure 10. Model-predicted nondimensional eddy volume corresponding to computed scour volume in Figure 9. The horizontal axis is discharge normalized by $1274 \mathrm{~m}^{3} / \mathrm{s}$.

characteristics are represented by $\delta z$ and $S_{f} ; A_{e}$ and $P$ represent eddy size and shape. The product of the nondimensional scour volume in step 1 and the reference scour volume computed in this step yields the reference dimensional scour volume, $v_{r s}$, for the change in discharge.

[35] 3. A nondimensional eddy sand volume is calculated that corresponds to the scour volume computed in step 2 (Figure 10).

[36] 4. Eddy sand volume dimension for the result from step 3 is calculated with the relation in Figure 11. The product of the result of step 3 and this step is a reference eddy volume, $v_{r e}$, used to scale the eddy scour with $v_{e} / v_{r e}$ where $v_{e}$ is the eddy sand volume at node $i$ at the current time step.

[37] 5. The scour at the node, $v_{e s}$, which is added to the local sand discharge $\left(q_{s}\right)$, is obtained from

$$
v_{e s}=v_{r s} \frac{v_{e}}{v_{r e}} .
$$

[38] The local sand discharge is modified to account for sand scour from the eddies with

$$
q s_{l i}=q s_{l i}+\frac{v_{e s}}{\delta t_{s}} c_{o i},
$$

where $l$ is the spatial index, $i$ is the grain size index, the equal sign denotes replacement of the left-hand variable by the right-hand quantity, and $\delta t_{s}$ is the sediment computation time step. Because the two-dimensional model operates with only one grain size, the distribution of sand sizes contributed to main stem transport is approximated with the distribution of tributary sand inputs, $c_{o}$, consistent with observations that eddies tend to store finer material than is present on the channel bed. 


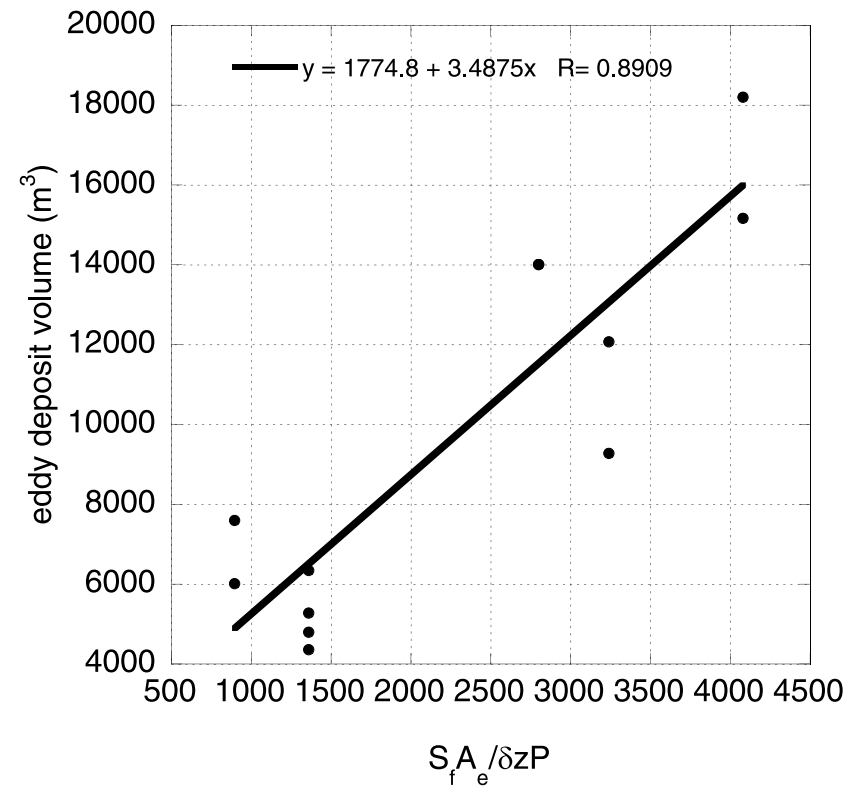

Figure 11. Model-predicted eddy volume used to dimensionalize the volume determined from Figure 10.

\subsubsection{Deposition in Eddies}

[39] The model was applied to seven two-dimensional modeling sites at discharges of 85, 142, 283, 425, 566, 849, $1274,2123,2830$, and $5660 \mathrm{~m}^{3} / \mathrm{s}$, and with three sand supplies. Sand supply rates were calculated from sand discharge rating curves for three different conditions (D. Topping, U.S. Geological Survey, written communication, 2000): a period following sustained high flows (near $2717 \mathrm{~m}^{3} / \mathrm{s}$ ) during 1983, which represent a relatively low

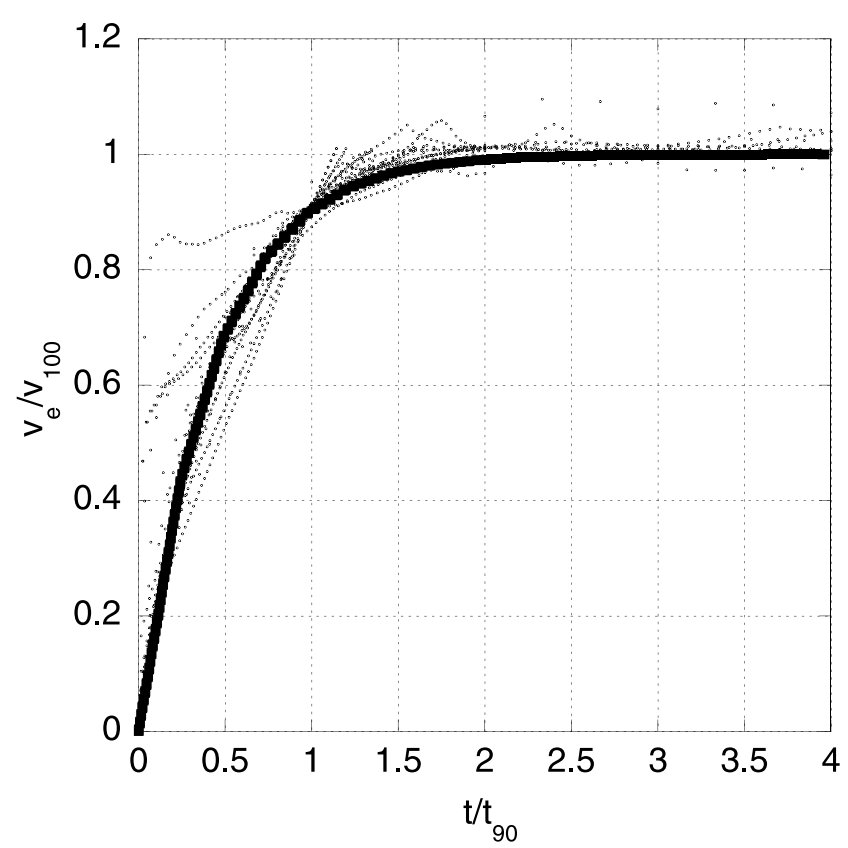

Figure 12. Nondimensional eddy deposition over nondimensional time computed with the two-dimensional model. Accumulation of sand in eddies follows a similar curve if volume is normalized by $v_{100}$ and time by $t_{90}$.

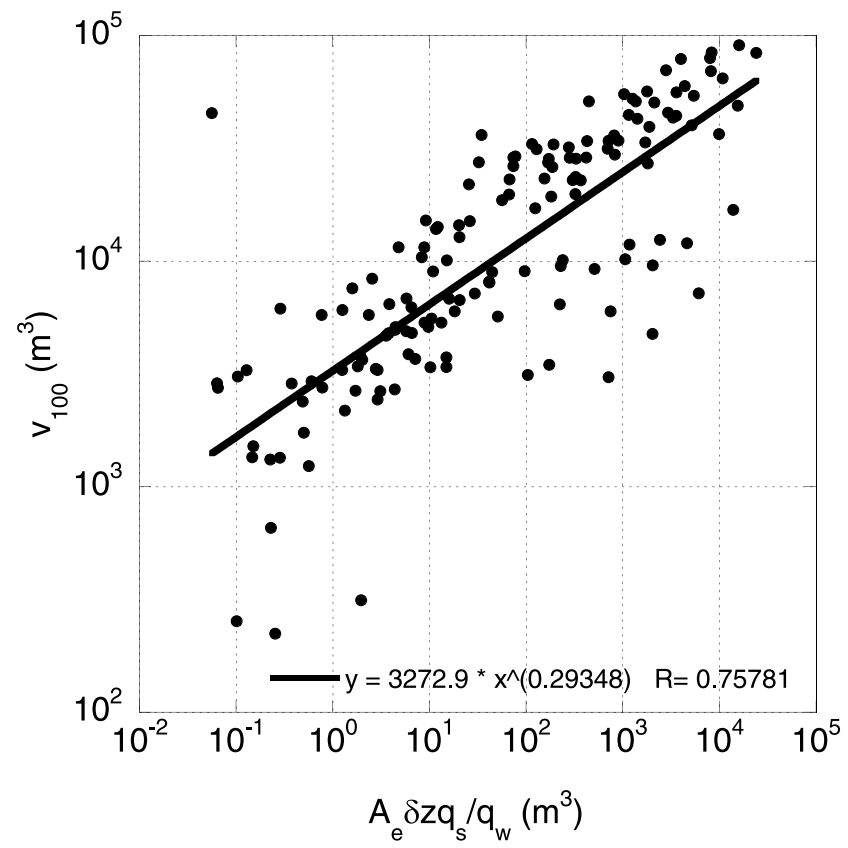

Figure 13. Model-predicted maximum eddy sand storage $\left(v_{100}\right)$ as a function of discharge $\left(q_{w}\right)$, eddy area $\left(A_{e}\right)$, sand discharge $\left(q_{s}\right)$, and increase in water surface elevation above $85 \mathrm{~m}^{3} / \mathrm{s}(\delta z)$.

sand supply; a period during a tributary flow in 1956 that represents a large sand supply; and a period after the first day of the 1996 experimental release, which represents an intermediate condition typical of the postdam river.

[40] Examination of two-dimensional model results revealed that the accumulation over time of sand in the eddies can be generally represented by

$$
v_{e}=v_{100}\left(1-e^{-k t / t_{90}}\right)
$$

where $v_{e}$ is the volume of sand in the eddy, $v_{100}$ is the maximum volume for the specified water and sand discharges, $k$ is a constant, and $t_{90}$ is the time required to fill the eddy to $90 \%$ full (Figure 12). A value for $k$ of 2.34 provides a good fit for the model applications with $\mathrm{R}=$ $0.96 ; v_{100}$ and $t_{90}$ vary with sand and water discharge and with each eddy modeled.

[41] The rate at which sand from the main stem is deposited in the eddy is determined from the derivative of (9):

$$
\frac{d v_{e}}{d t}=\frac{k}{t_{90}}\left(v_{100}-v_{e}\right)
$$

[42] The independent variables for eddy volume are taken to be eddy area $\left(A_{e}\right)$, change in water surface elevation above the stage at $28 \mathrm{~m}^{3} / \mathrm{s}$ (designated by $\delta z$ ), and sand concentration (sediment discharge $\left(q_{s}\right)$ /water discharge $\left.\left(q_{w}\right)\right)$. The independent variables for the characteristic timescale $\left(t_{90}\right)$ are $A_{e}, \delta z$, and $q_{s}$. These variables can be grouped into nondimensional variables $t^{*}=t_{90} q_{s} /\left(A_{e} \delta z\right)$ and $v^{*}=v_{100} q_{w} /\left(A_{e} \delta z q_{s}\right)$. The value of $v_{100}$ is determined from two-dimensional model results shown in Figure 13. 


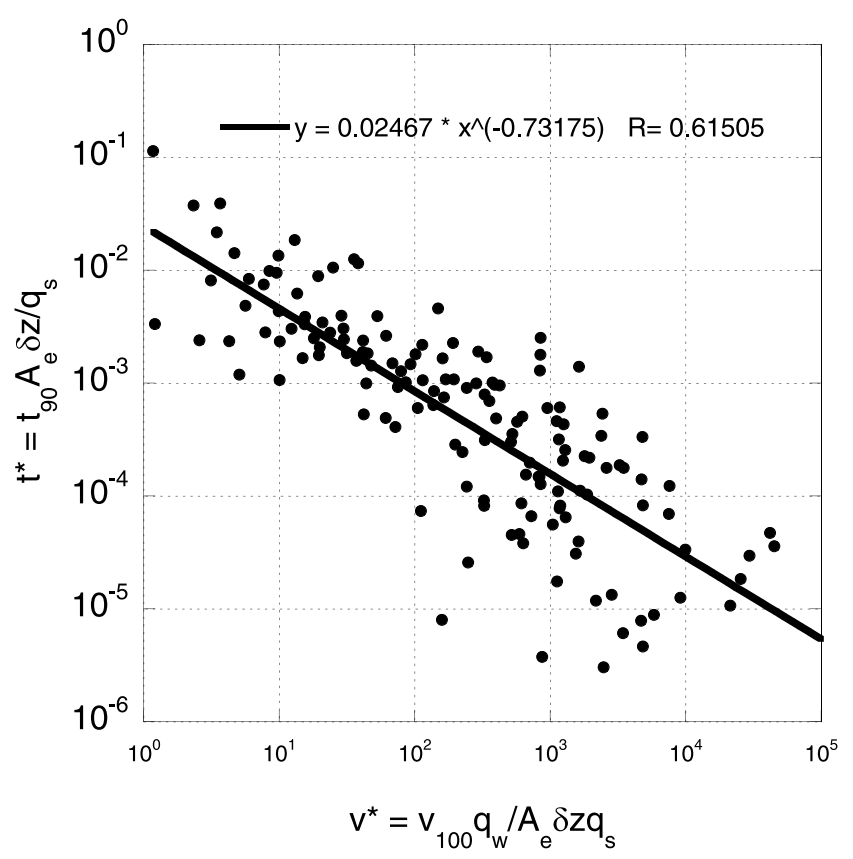

Figure 14. Model predictions for the time required to fill the eddy to $90 \%$ of $v_{100}$.

Results from the two-dimensional model shown in Figure 14 are used to determine $t_{90}$. The change in water surface elevation was taken from rating curves developed by the Northern Arizona Sandbar Studies group (written communication, 2004) where available or by using the method of Wiele and Torizzo [2003] with water surface elevations at $226 \mathrm{~m}^{3} / \mathrm{s}$ and $2745 \mathrm{~m}^{3} / \mathrm{s}$ discussed previously. Eddy areas were provided by the Utah State Geomorphology Lab [Schmidt et al., 2004].

\section{Model Application}

\subsection{Experimental Release}

[43] In late summer and early fall of 2004, sediment inputs from the Paria River were sufficient to trigger a dam release plan designed to increase storage of tributary sands [U.S. Department of the Interior, 2002, 2004]. Lowdischarge releases from the dam were designed to reduce main stem sand transport and allowed temporary storage of sand on the channel bottom. The low releases limited export of Paria inputs out of Marble Canyon until mid-November, when a discharge of $1187 \mathrm{~m}^{3} / \mathrm{s}$ was released for 2.5 days to redistribute sand to high-elevation deposits along the channel sides. This was followed by 6 days of steady flow at $226 \mathrm{~m}^{3} / \mathrm{s}$ and a subsequent regime of daily fluctuating flows (Figure 15). A discharge of $1274 \mathrm{~m}^{3} / \mathrm{s}$ was released from Glen Canyon Dam in April 1996 in a test of the effectiveness with which sandbars along the channel sides could be replenished by high releases. Large sandbars were deposited at higher elevations through most of Grand Canyon and lower Marble Canyon [Schmidt, 1999; Hazel et al., 1999; Kearsley et al., 1999], but lower-elevation sandbars closer to the dam, where the main stem sand supply was presumably lower, were scoured [Schmidt, 1999; Schmidt et al., 2004]. The release pattern in 2004, and its triggering by significant Paria inputs, was in response to the scour of bars in upper Marble Canyon and was intended to promote deposition in that length of river. Following the high release, which lasted 60 hours, and a steady low flow of $226 \mathrm{~m}^{3} / \mathrm{s}$ for six days, fluctuating flows were resumed. The Paria River and the Little Colorado River, which meets the Colorado River at RM 62, flowed and contributed sediment periodically after the November high release, and the fluctuating flows were sufficiently high to export some of that sediment.

\subsection{Flow and Sediment Measurements}

[44] Recognition of the variability of sand transport as a function of sand supply and the observed variability in sediment discharge relations [Topping et al., 2000a, 2000b] has motivated the GCMRC to make or support frequent measurements at several locations by using different measurement methods [Topping et al., 2004; Melis et al., 2003]. In addition to a long-term gauging station near Phantom Ranch, near RM 87 (U.S. Geological Survey (USGS) Colorado River near Grand Canyon), sediment measurement sites were established at RM 30 and RM 61, about one-half mile above the site of a discontinued USGS gauging station (Figure 1). The gauging station near RM 87 is especially significant because of its longevity; it is easily accessible by a well-maintained trail, facilitating more frequent measurements and maintenance of automatic sampling equipment; has a cableway; and has been used to represent the flux of sediment out of the upper reaches of the river. It also marks the downstream extent of our modeled reaches.

[45] The Paria River delivers sediment to the Colorado River less than 1 mile below Lees Ferry, RM 0 (Figure 1) and is the major contributor of sediment to Marble Canyon since the closure of Glen Canyon Dam. A USGS gauging station on the Paria River just above its mouth provides a record of discharge. Sand flux from the Paria River is calculated by using a sediment rating curve based on measurements of bed material size and a model of transport rates as a function of discharge that has shown good

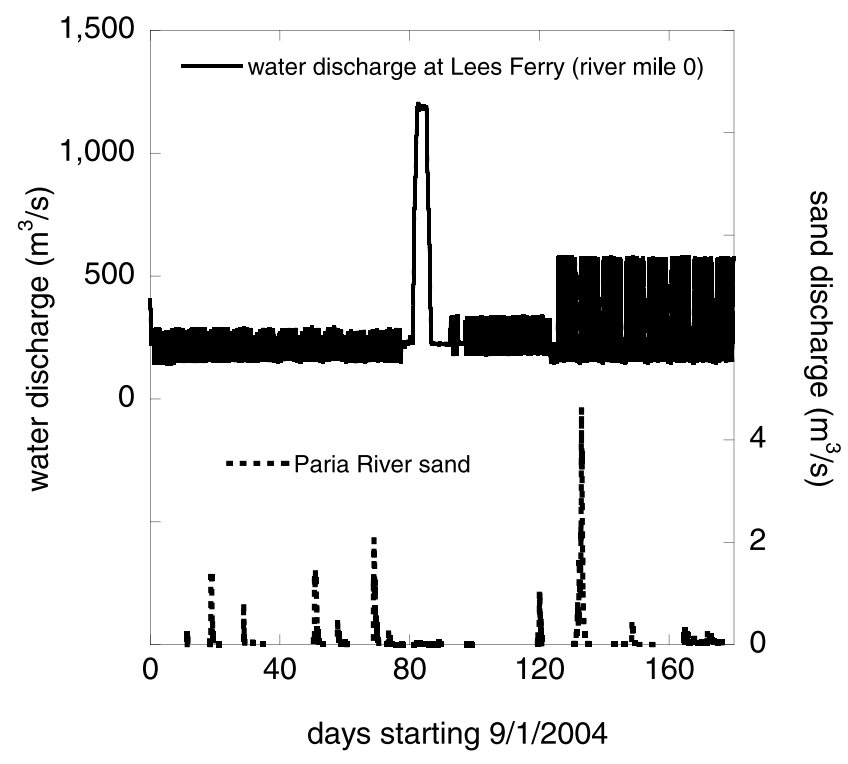

Figure 15. Graph showing hydrograph at Lees Ferry between 1 September 2004 and 1 March 2005. 


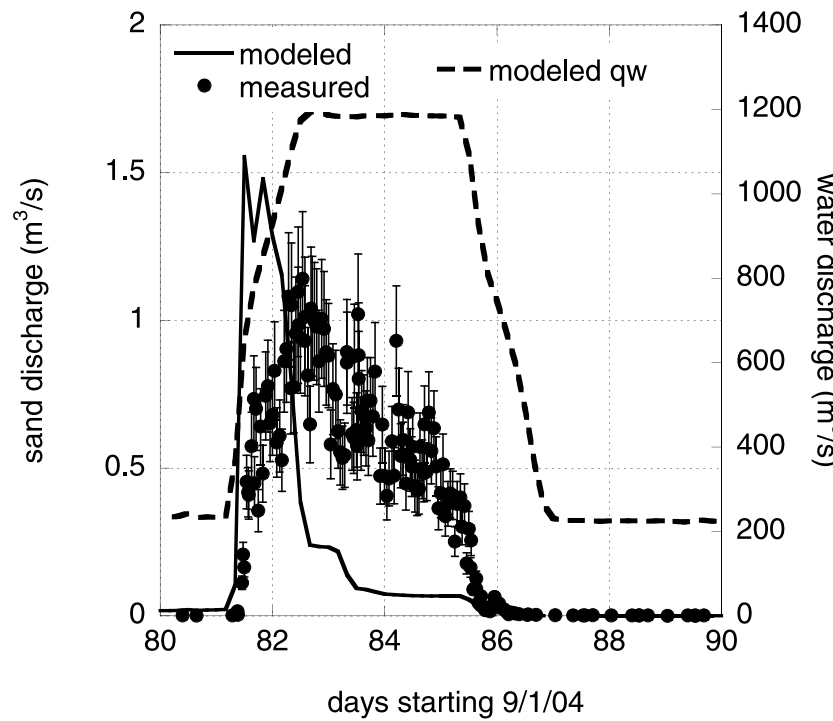

Figure 16. Model-predicted and measured sand discharge during the November 2004 experimental release at river mile 30 . Error bars represent an estimated $20 \%$ error in the measurements.

agreement with measurements [Topping, 1997]. The difference between import of sediment from the Paria River and export past the gauging station near Grand Canyon has been used to construct a sediment budget to assess the retention or loss of sand in Marble Canyon [Topping et al., 2004].

\subsection{Model Results}

[46] The model was applied to the period 1 September 2004 to 1 March 2005. The initial conditions for sand on the bed and in the eddies were estimated on the basis of field surveys and an analysis of bed sand size data. The initial eddy volumes were estimated by running the model with

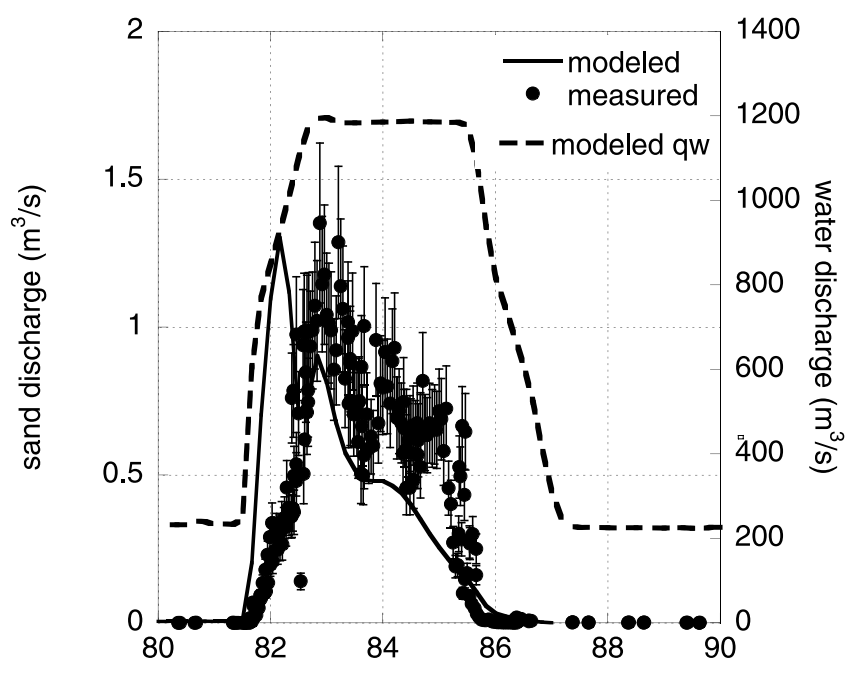

days starting $9 / 1 / 04$

Figure 17. Model-predicted and measured sand discharge during the November 2004 experimental release at river mile 61. Error bars represent an estimated $20 \%$ error in the measurements.

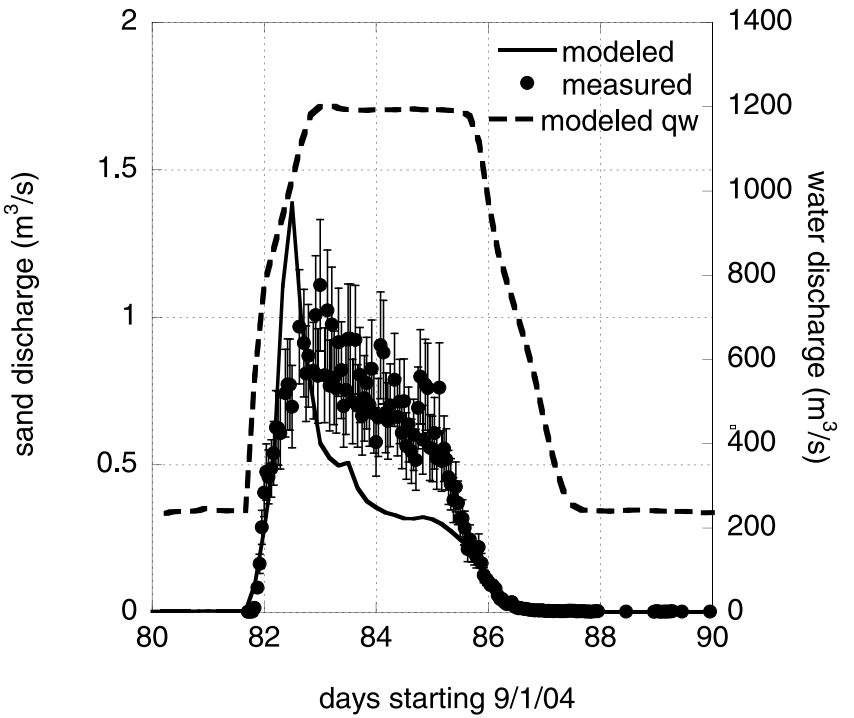

Figure 18. Model-predicted and measured sand discharge during the November 2004 experimental release at river mile 87 . Error bars represent an estimated $20 \%$ error in the measurements.

low fluctuating flows and large initial sand volumes until eddy change was small. Topping et al. [2005] concluded that channel grain size distributions are typically about two to four times the size of tributary inputs in the absence of recent tributary activity; consequently, a thin layer of coarse sand was specified as the initial bed condition. The model results are not sensitive to the sand thickness because sand two to four times the size of Paria inputs is transported at a much slower rate than the Paria inputs.

[47] Model predictions of total sand discharge at the three measurement sites show that the model tends to over predict transport rates during the early part of the high flow, especially at RM 30 (Figure 16) and to underpredict

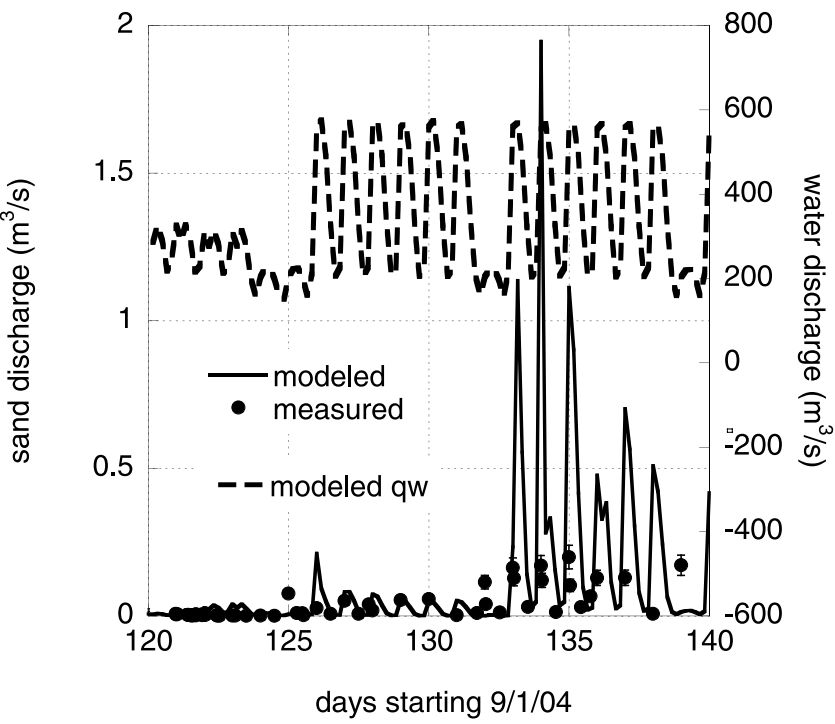

Figure 19. Model-predicted and measured sand discharge between 1 September 2004 and 1 March 2005 at river mile 30 . 


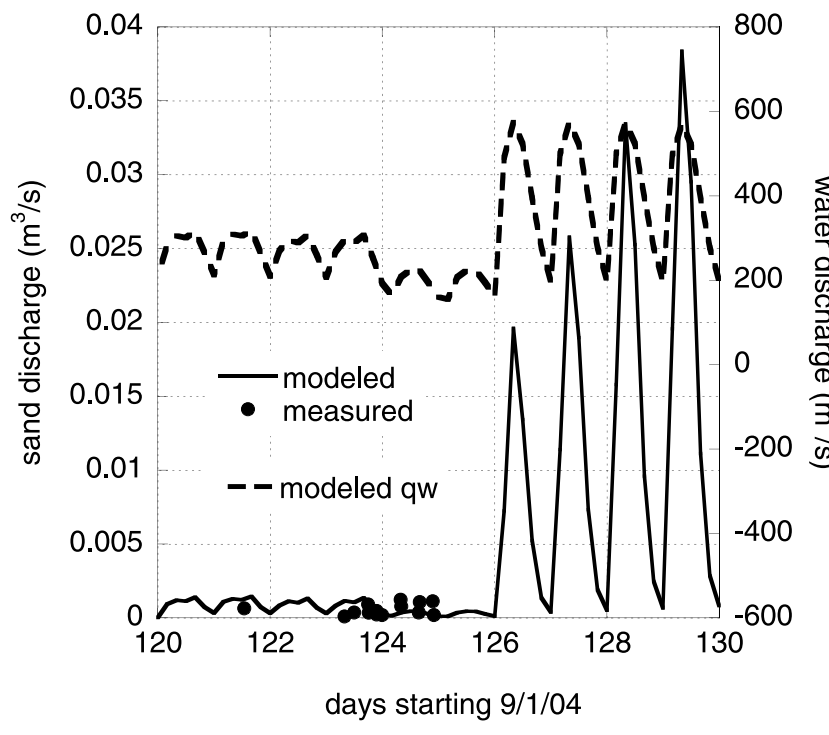

Figure 20. Model-predicted and measured sand discharge between 1 September 2004 and 1 March 2005, at river mile 61 .

transport rates as the high flow progressed at RM 30 and to a lesser extent at RM 61 and RM 87 (Figures 17 and Figure 18). Model predictions of sand transport during the fluctuating flows following the November 2004 high release show a similar pattern, although small timing errors in the model predictions of discharge can make comparison difficult. Model overprediction of transport rates at RM 30 after the November high release (Figure 19) indicate the model is more responsive to tributary sediment inputs than is apparent in the measurements. The model appears to be consistent with measurements where they are available at RM 61 (Figure 20) and 87 (Figure 21). Measurements at RM 87 show two occasions when transport was higher than pre-

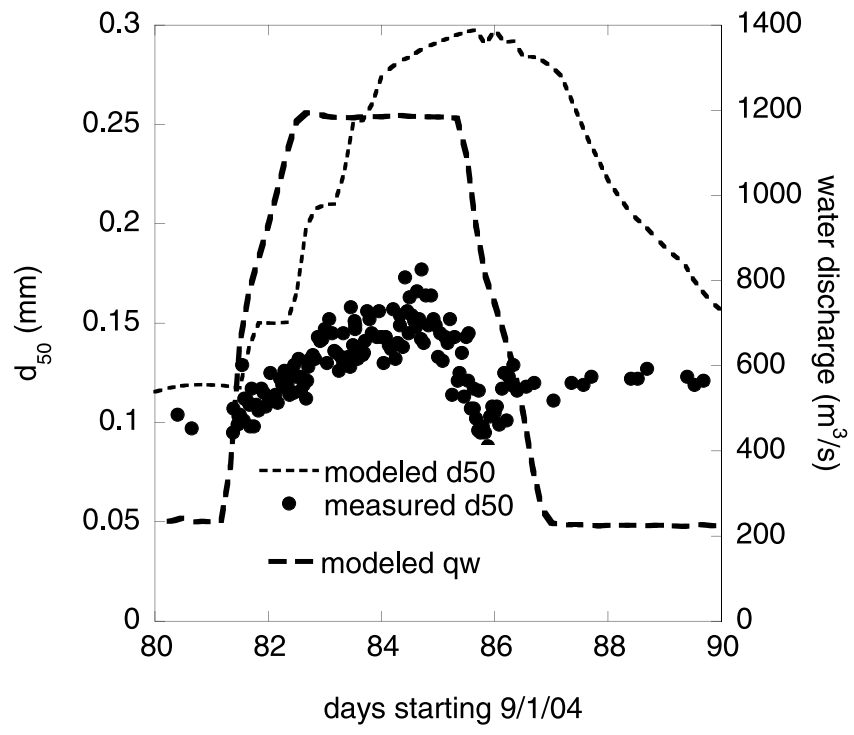

Figure 22. Model-predicted and measured sand, $d_{50}$, during the November 2004 experimental release at river mile 30 .

dicted despite low discharge (Figure 21). Discrepancies such as this could be at least partially the result of local effects, such as slumping of sandbars or small tributary events. Model predictions of grain size, represented by the median, $\mathrm{d}_{50}$, show that the model generally predicts coarser grain sizes in transport than is measured at RM 30 (Figure 22) but shows reasonable agreement at both RM 61 (Figure 23) and 87 (Figure 24) during most of the November 2004 high flow. The model tends to predict coarser grain sizes than were measured near the end of the high flow and during and after the decline of the discharge at the end of the high flow when transport rates were very low. Less frequent measurements make direct

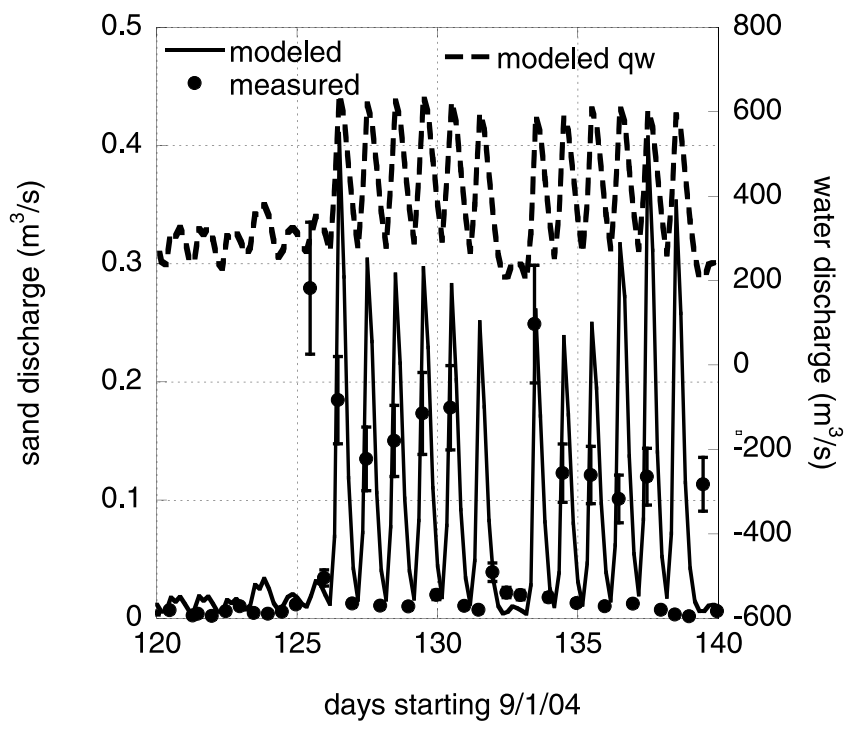

Figure 21. Model-predicted and measured sand discharge after the November 2004 experimental release at river mile 87 . Error bars represent an estimated $20 \%$ error in the measurements.

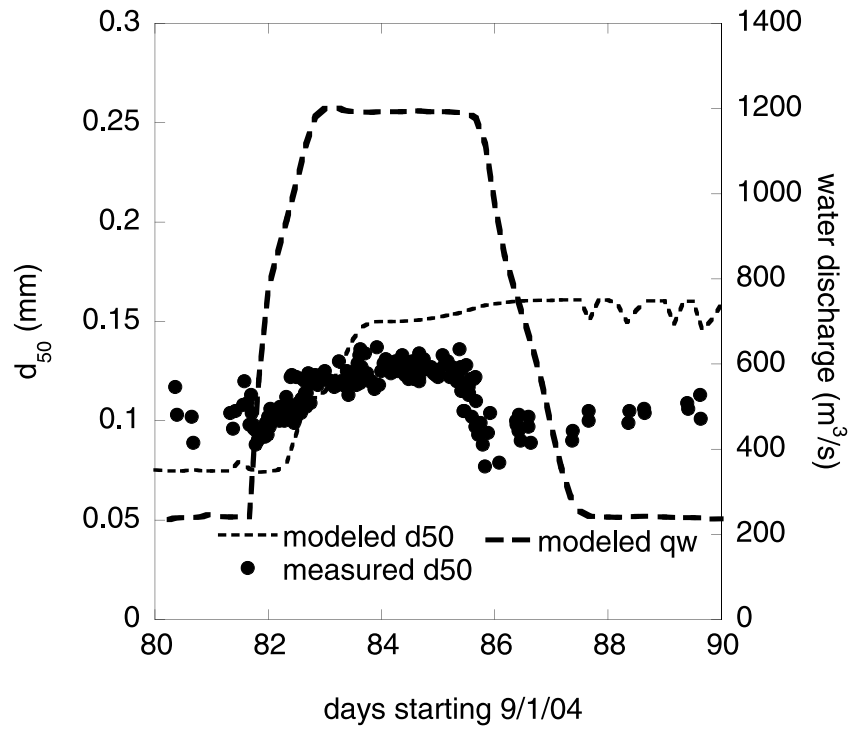

Figure 23. Model-predicted and measured sand, $d_{50}$, during the November 2004 experimental release at river mile 61 . 


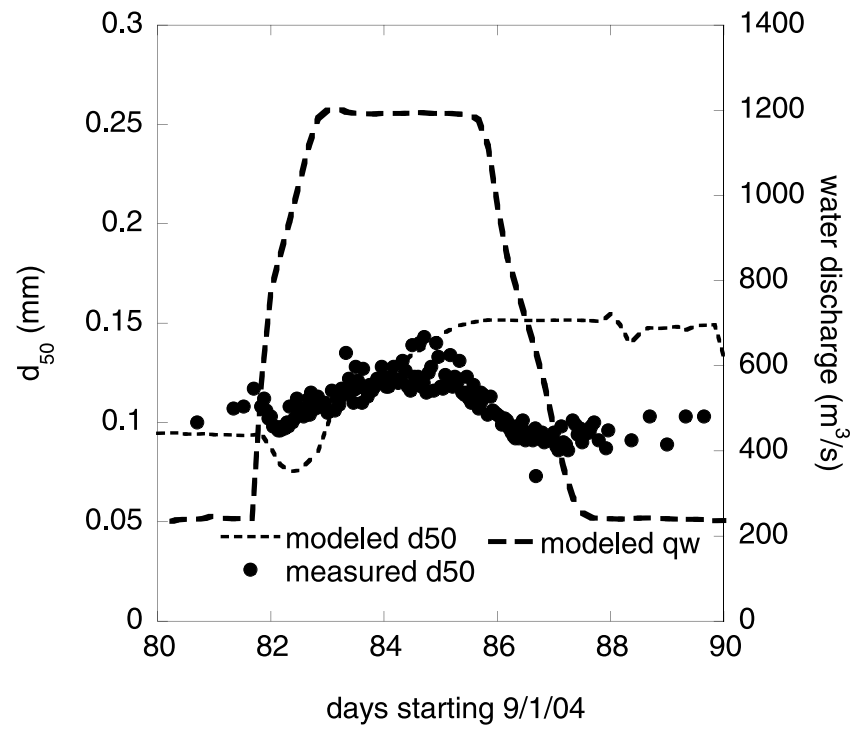

Figure 24. Model-predicted and measured sand, $d_{50}$, during the November 2004 experimental release at river mile 87.

comparison with field sampling during the fluctuating flows in January through February 2005 more difficult, but the model predictions at RM 30 (Figure 25), 61 (Figure 26), and 87 (Figure 27) show reasonable agreement with available measurements.

[48] A critical component of the assessment of transport rates for management purposes and one that integrates the range of releases from the dam is the cumulative mass discharge at RM 87. The model agrees well with measurements for this aspect of the sand transport (Figure 28). Sensitivity of the model to our estimate of characteristic bed roughness length was tested by comparing model predictions of the cumulative mass flux at RM 87 with roughness lengths of 0.8 and $1.2 \mathrm{~m}$. The cumulative mass flux at RM 87 was reduced by $6 \%$ with a $20 \%$ increase in roughness length and increased by $6 \%$ with a $20 \%$ decrease in roughness length.

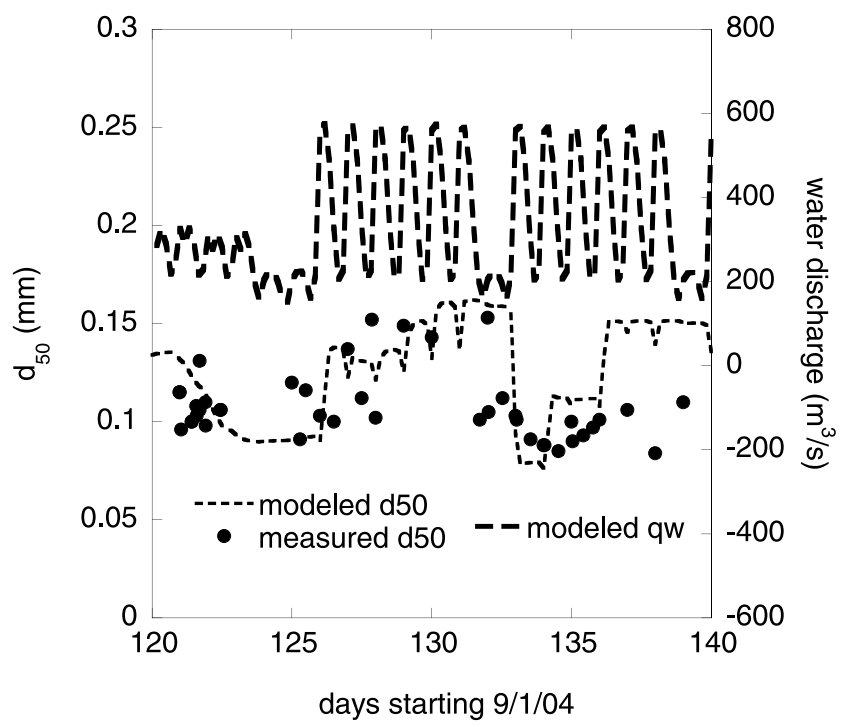

Figure 25. Model-predicted and measured sand, $d_{50}$, during the November 2004 experimental release at river mile 30 .

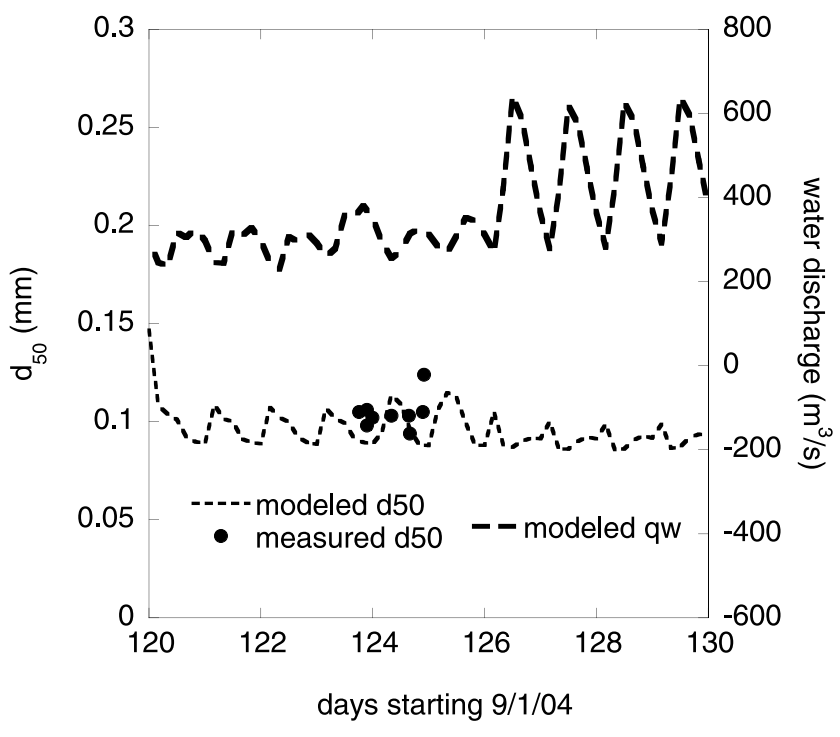

Figure 26. Model-predicted and measured sand, $d_{50}$, during the November 2004 experimental release at river mile 61 .

[49] Surveys of sandbars in five reaches a few kilometers long were completed prior to the high release and during the low steady flow immediately after the release (NAU Sandbar studies, written communication, 2005). Changes in sand volume between these two surveys were computed (M. Breedlove, Utah State University, written communication, 2005). Model prediction of changes in eddy storage with the uncalibrated algorithms is shown with the survey data in Figure 29. The eddy areas used in the model development were also used for the comparisons with measurements. Eddy sandbar response is quite variable with distance downstream. Both the model and measurements show a much smaller range in eddy response than occurred during the 1996 high release during which eddy thickness changed by up to about $3 \mathrm{~m}$ [Hazel et al., 1999].

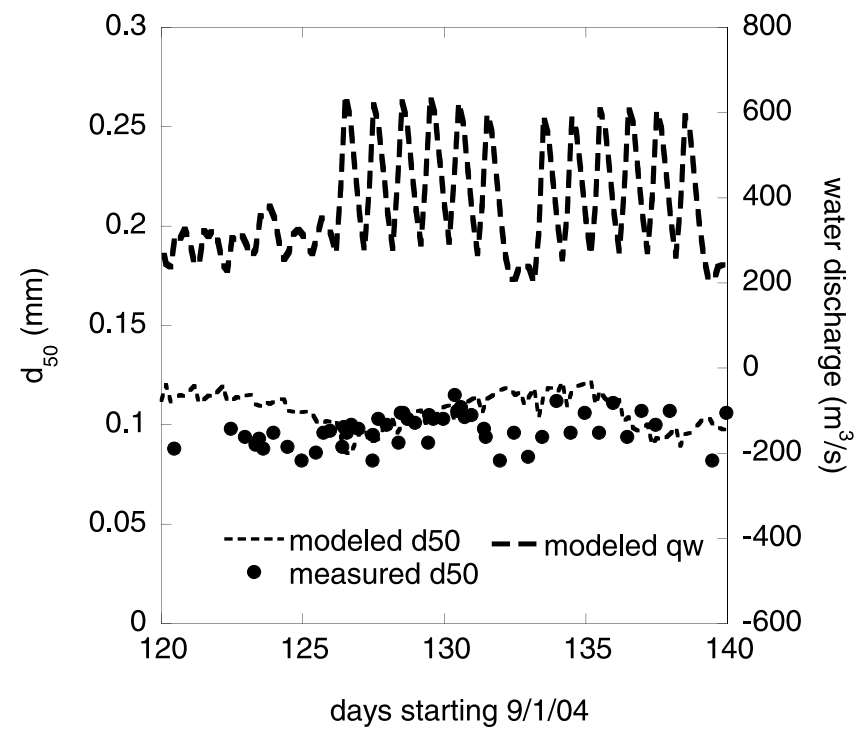

Figure 27. Model-predicted and measured sand, $d_{50}$, during the November 2004 experimental release at river mile 87 . 


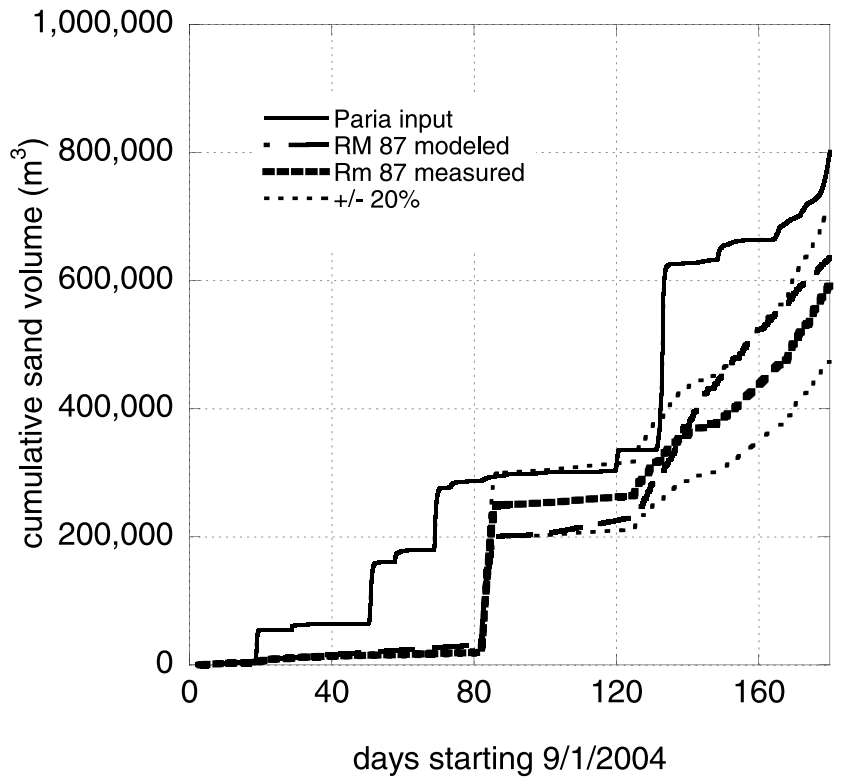

Figure 28. Model-predicted and measured cumulative sand volume at river mile 87 between 1 September 2004 and 1 March 2005. Error bounds represent an estimated $20 \%$ error in the measurements.

The model shows a trend similar to that in the data, especially in a zone of deposition in central Marble Canyon (around river miles 25-40), but with a lower magnitude. Significant deviation between model and measurement exists at the NAU sites further downstream: the model shows an increase, whereas the data indicate a net loss of sand. Further comparison is hindered by the limited spatial extent of the highresolution ground survey. Evaluation of the source and sink algorithms is further hampered by uncertainties in the initial bed and eddy conditions, the respresentativeness of the NAU

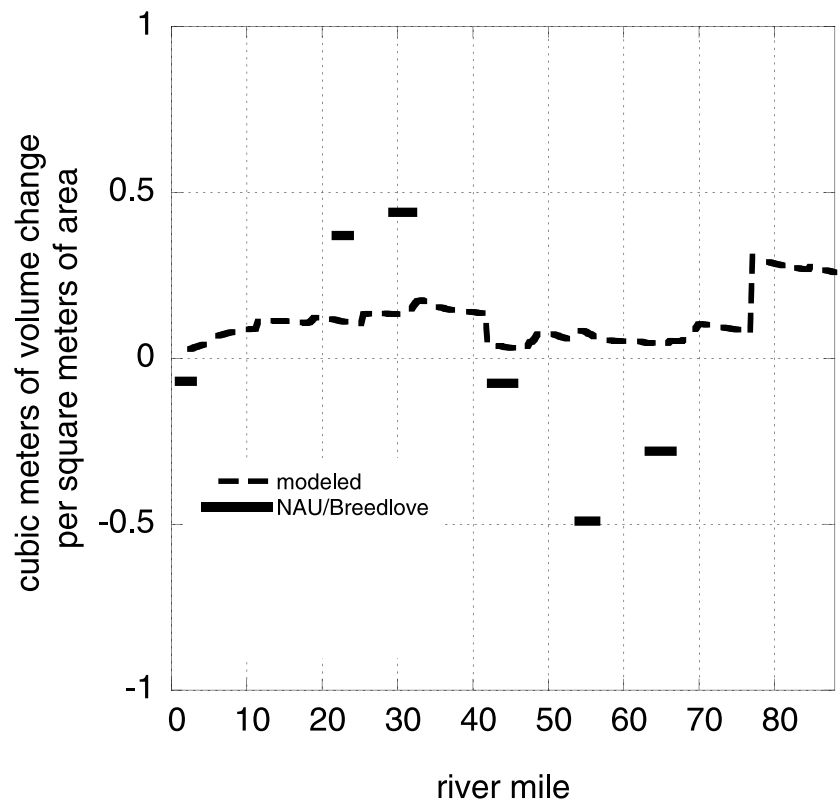

Figure 29. Model-predicted and measured change in total eddy sand volume. Both model and measurements show small changes in sand deposit thickness compared to changes that occurred during the 1996 high flow.

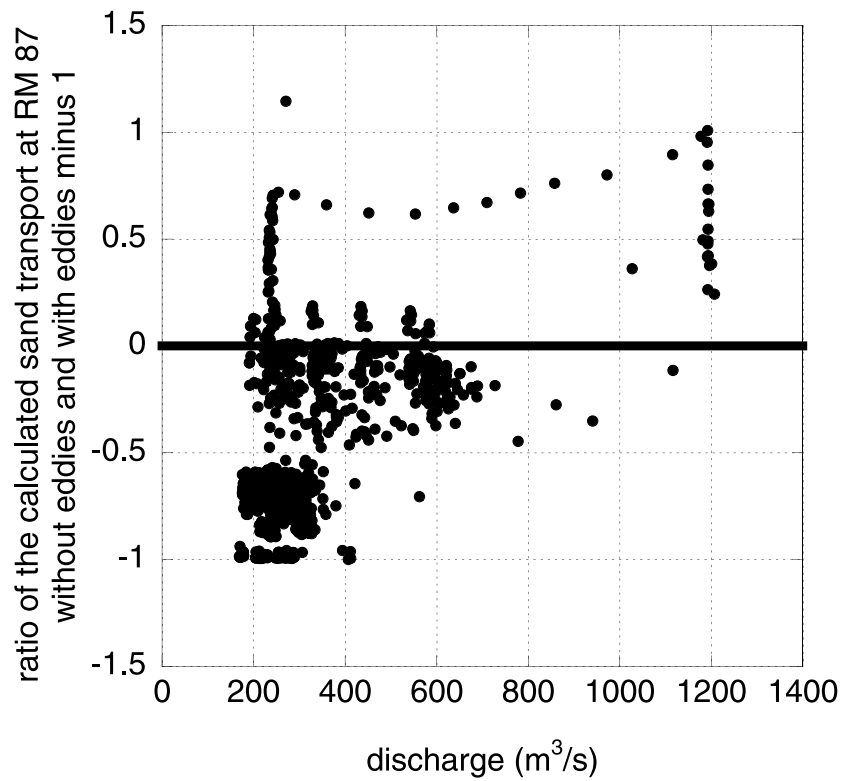

Figure 30. Ratio of sand transport rates at river mile 87 calculated with and without eddies included in the model as a function of water discharge.

sites, and the generally small proportion of sand exchanged with the eddies. Further, the model does not account for sand loss by slumping, a potentially significant [Andrews et al., 1999] but poorly understood process under these conditions that could explain some of the overestimation by the model of sand volumes in the eddies.

[50] The ratio of main stem sand transport rates at RM 87 calculated with and without the eddies demonstrates the effect of the eddies on main stem transport (Figure 30). Scour or temporary storage of sand in the eddies affect the magnitude of the transport over short timescales. Integrated over longer timescales, the differences would be smaller. At the end of the 180 day simulation, the difference between the cumulative sand volume that passed RM 87 with and without eddies was calculated to be $9 \%$. The effect of the eddies was also mitigated in this simulation compared to more typical postdam conditions because the dam releases were reduced to promote storage of sand on the channel bed.

\section{Summary}

[51] We have developed a reach-averaged model for a complicated flow and sand transport environment in which information concerning channel properties is incomplete. Data needs are minimized by using reach-averaged properties to represent the channel hydraulic geometry. Important aspects of the sand storage that cannot be represented in one dimension are included by parameterizing the results of a multidimensional model that are extrapolated to the characteristic reaches. Pools, which can be represented in one dimension but which are not well represented by reachaveraged topography, were identified by significant deviations from the reach-averaged shape, and their effects on streamwise transport and storage included in the sand routing. Sand transport over a boundary with meter-scale roughness is outside the range of conditions for conventional transport relations; therefore a new algorithm was developed for these conditions. 
[52] The model was applied to a $140-\mathrm{km}$ reach of the Colorado River in Grand Canyon, an environment in which most contemporary sand storage occurs in eddies sheltered from the main flow. The test period of 175 days corresponds to a large input of sand at the upstream end of the model reach, followed by a dam release schedule at Glen Canyon Dam intended to store sediment in eddy deposits. The model generally agrees well with measurements of sand discharge and median grain size at RM 61 and 87 and with cumulative sand transport at RM 87. At RM 30, the model overpredicts sand transport rates during the early part of the high release. The model has no free parameters that were tuned to fit model predictions to data. The better agreement between model and observation over longer distances from the source is likely related to the reach-averaged nature of the model. Fluctuations from local variations in hydraulic geometry or sand storage will average over longer distances and more closely adhere to reach-averaged responses predicted by the model.

[53] Although results presented here generally agree well with measurements, the model should be applied with the awareness that modeling components in these comparisons are not uniquely constrained. The comparisons at the RM 87 gauging station do not represent a conclusive test of the channel-side representation in the model because under the conditions modeled, the contribution of changes in eddy storage to the cumulative sand volume transported past RM 87 were about $9 \%$ of the total transport. More accurate assessments of side-channel storage of sand could be made by using the one-dimensional predictions of large-scale transport to establish upstream sand boundary conditions for applications of more detailed multidimensional models, and extended over longer time spans with the addition of physically based or empirical models of sandbar erosion.

[54] Acknowledgments. Funding was provided by the Grand Canyon Monitoring and Research Center. Discussions with and data shared by Joe Hazel, Matt Kaplinski, Ted Melis, Jack Schmidt, David Topping, and Scott Wright contributed significantly to our project. Insightful and careful reviews by an anonymous reviewer, Tim Randle, Gary Parker, and Francisco Simoes were very helpful.

\section{References}

Anderson, D. A., J. C. Tannehill, and R. H. Pletcher (1984), Computational Fluid Mechanics and Heat Transfer, 599 pp., Hemisphere, Washington, D. C.

Andrews, E. D., C. E. Johnston, J. C. Schmidt, and M. Gonzales (1999), Topographic evolution of sand bars, in The Controlled Flood in Grand Canyon, Geophys. Monogr. Ser, vol. 110, edited by R. H. Webb et al., pp. 117-130, AGU, Washington, D. C.

Bennett, J. P., and C. F. Nordin (1977), Simulation of sediment transport and armoring, Hydrol. Sci. Bull., 22, 555-569.

Breedlove, M. J., and S. Mietz (2002), A guide to the Colorado River in the Grand Canyon (from Glen Canyon Dam to Pierce Ferry), technical report, Grand Canyon Monitor. and Res. Cent. U.S. Geol. Surv., Flagstaff, Ariz.

Cluer, B. L. (1995), Cyclic fluvial processes and bias in environmental monitoring, Colorado River in Grand Canyon, J. Geol., 95, 411-421.

Einstein, H. A. (1950), The bed load function in open channel flows, Tech. Bull. 1026, U.S. Dept. of Agric., Washington, D. C.

Garcia, M., and G. Parker (1991), Entrainment of bed sediment into suspension, J. Hydraul. Eng., 117, 414-435.

Graf, J. B. (1995), Measured and predicted velocity and longitudinal dispersion at steady and unsteady flow, Colorado River, Glen Canyon Dam to Lake Mead, Water Resour. Bull., 31, 265-281.

Grams, P. E. (2006), Sand transport over a coarse and immobile bed, Ph.D. dissertation, 193 pp., Johns Hopkins Univ., Baltimore, Md.
Grams, P. E., P. R. Wilcock, and S. M. Wiele (2005), Entrainment and nonuniform transport of fine sediment in coarse-bedded rivers, in River, Coastal and Estuarine Morphodynamics, edited by G. Parker and M. Garcia, pp. 1073-1081, Taylor and Francis Group, London.

Griffin, E. R. (1997), Use of a geographic information system to extract topography for modeling flow in the Colorado River through Marble and Grand Canyons, M. S. thesis, 113 pp., Univ. of Colo., Boulder.

Griffin, E. R., and S. M. Wiele (1997), Refined calculation of hydraulic geometry in the Colorado River through Grand Canyon, Eos Trans. $A G U, 78(46)$, Fall Meet. Suppl., 288.

Hazel, J. E., M. Kaplinski, R. A. Parnell, M. F. Manone, and A. R. Dale (1999), Topographic and bathymetric changes at thirty-three long-term study sites, in The Controlled Flood in Grand Canyon, Geophys. Monogr. Ser., vol. 110, edited by R. H. Webb et al., pp. 161-183, AGU, Washington, D. C.

Hazel, J. E. Jr., D. J. Topping, J. C. Schmidt, and M. Kaplinski (2006), Influence of a dam on fine-sediment storage in a canyon river, J. Geophys. Res., 111, F01025, doi:10.1029/2004JF000193.

Howard, A. D., and R. Dolan (1981), Geomorphology of the Colorado River in the Grand Canyon, J. Geol., 89, 269-298.

Kearsley, L. H., R. D. Quartaroli, and M. J. C. Kearsley (1999), Changes in the number and size of campsites as determined by inventories and measurements, in The Controlled Flood in Grand Canyon, Geophys. Monogr. Ser, vol. 100, edited by R. H. Webb et al., pp. 147-159, AGU, Washington, D. C.

Leopold, L. B. (1969), The rapids and the pools-Grand Canyon, U.S. Geol. Surv. Prof. Pap., 669, 131-145.

Melis, T. S. (1997), Geomorphology of debris flows and alluvial fans in Grand Canyon National Park and their influence on the Colorado River below Glen Canyon Dam, Arizona, Ph.D. dissertation, 490 pp., Univ. of Ariz., Tucson.

Melis, T. S., R. H. Webb, P. G. Griffiths, and T. J. Wise (1994), Magnitude and frequency data for historic debris flows in Grand Canyon National Park and vicinity, Arizona, U.S. Geol. Surv. Water Resour. Invest. Rep., 94-4214, 285 pp.

Melis, T. S., D. J. Topping, and D. M. Rubin (2003), Testing laser-based sensors for continuous in situ monitoring of suspended sediment in the Colorado River, Arizona, IAHS Publ., 283, 21-27.

Randle, T. J., and E. L. Pemberton (1987), Results and analysis of STARS modeling efforts of the Colorado River in Grand Canyon, NTIS PB88183421/AS, Bur. of Reclamation U.S. Dept. of the Int., Washington, D. C.

Rouse, H. (1937), Modern conceptions of the mechanics of turbulence, Trans. Am. Soc. Civ. Eng., 102, 463-543.

Rubin, D. M., J. C. Schmidt, and J. N. Moore (1990), Origin, structure, and evolution of a reattachment bar, Colorado River, Grand Canyon, Arizona, J. Sediment. Petrol., 60, 982-991.

Schmidt, J. C. (1987), Geomorphology of alluvial-sand deposits, Colorado River, Grand Canyon National Park, Arizona, Ph.D. dissertation, Johns Hopkins Univ., Baltimore, Md.

Schmidt, J. C. (1990), Recirculating flow and sedimentation in the Colorado River in Grand Canyon, Arizona, J. Geol., 98, 709-724.

Schmidt, J. C. (1999), Summary and synthesis of geomorphic studies conducted during the 1996 controlled flood in Grand Canyon, in The Controlled Flood in Grand Canyon, Geophys. Monogr. Ser., vol. 110, edited by R. H. Webb et al., pp. 329-341, AGU, Washington, D. C.

Schmidt, J. C., and J. B. Graf (1990), Aggradation and degradation of alluvial sand deposits, 1965 to 1986, Colorado River, Grand Canyon National Park, Arizona, U.S. Geol. Surv. Prof. Pap., 1493, 74 pp.

Schmidt, J. C., and D. M. Rubin (1995), Regulated streamflow, fine-grained deposits, and effective discharge in canyons with abundant debris fans, in Natural and Anthropogenic Influences in Fluvial Geomorphology, Geophys. Monogr. Ser, vol. 89, edited by J. E. Costa et al., pp. 177-195, AGU, Washington, D. C.

Schmidt, J. C., D. J. Topping, P. E. Grams, and J. E. Hazel (2004), Systemwide changes in the distribution of fine sediment in the Colorado River corridor between Glen Canyon Dam and Bright Angel Creek, Arizona, final report, Grand Canyon Monitor. and Res. Cent. U.S. Geol. Surv., Flagstaff, Ariz.

Topping, D. J. (1997), Physics of flow, sediment transport, hydraulic geometry, and channel geomorphic adjustment during flash floods in the ephemeral river, the Paria River, Utah and Arizona, Ph.D. dissertation, Univ. of Wash., Seattle.

Topping, D. J., D. M. Rubin, and L. E. Vierra, Jr. (2000a), Colorado river sediment transport: 1 . Natural sediment supply limitation and the influence of Glen Canyon Dam, Water Resour. Res., 36, 515-542. 
Topping, D. J., D. M. Rubin, J. M. Nelson, P. J. Kinzel, III, and I. C. Corson (2000b), Colorado river sediment transport: 2. Systematic bed-elevation and grain-size effects of sand supply limitation, Water Resour. Res., 36, $543-570$.

Topping, D. J., T. S. Melis, D. M. Rubin, and S. A. Wright (2004), Highresolution monitoring of suspended-sediment concentration and grain size in the Colorado River in Grand Canyon using a laser-acoustic system, in Proceedings of the Ninth International Symposium on River Sedimentation, October 18-21, 2004, Yichang, China, edited by C. Hu and Y. Tan, pp. 2507-2514, Tsinghua Univ. Press, China.

Topping, D. J., D. M. Rubin, and J. C. Schmidt (2005), Regulation of sand transport in the Colorado River by changes in the surface grain size of eddy sandbars over multi-year timescales, Sedimentology, 52, 1133 1153 .

U.S. Department of the Interior (1995), Operation of Glen Canyon Dam: Final environmental impact statement, Colorado River Storage Project, Coconino County, Arizona, report, 337 pp., Salt Lake City, Utah.

U.S. Department of the Interior (2002), Proposed experimental releases from Glen Canyon Dam and removal of non-native fish: Environmenta assessment, report, 112 pp., Bur. of Reclamation Upper Colo. Reg., Salt Lake City, Utah.

U.S. Department of the Interior (2004), Proposed experimental actions for water years 2005-2006 Colorado River, Arizona, in Glen Canyon National Recreation Area and Grand Canyon National Park: Draft Supplemental Environmental Assessment, report, 26 pp., Bur. of Reclamation Upper Colo. Reg., Salt Lake City, Utah.

van Rijn, L. C. (1984), Sediment transport, part II: Suspended load transport, J. Hydraul. Eng., 110, 1613-1641.

Webb, R. H., P. T. Pringle, and G. R. Rink (1989), Debris flows from tributaries of the Colorado River, Grand Canyon National Park, Arizona,, U.S. Geol. Surv. Prof. Pap., 1492, 39 pp.

Wiele, S. M. (1997), Modeling of flood-deposited sand distributions for a reach of the Colorado River below the Little Colorado River, Grand Canyon, Arizona, U.S. Geol. Surv. Water Resour. Invest. Rep., 974168,15 .
Wiele, S. M., and E. R. Griffin (1997), Modifications to a one-dimensional model of unsteady flow in the Colorado River through the Grand Canyon, U.S. Geol. Surv. Water Resour. Invest., 97-4046.

Wiele, S. M., and J. D. Smith (1996), A reach-averaged model of diurnal discharge wave propagation down the Colorado River through the Grand Canyon, Water Resour. Res., 32, 1375-1386.

Wiele, S. M., and M. Torizzo (2003), A stage-normalized function for the synthesis of stage-discharge relations for the Colorado River in Grand Canyon, Arizona, U.S. Geol. Surv. Water Resour. Invest. Rep., 03-4037.

Wiele, S. M., and M. Torizzo (2005), Modelling of sand deposition in archeologically significant reaches of the Colorado River in Grand Canyon, USA, in Computational Fluid Dynamics: Applications in Environmental Hydraulics, edited by P. Bates, S. Lane, and R. Ferguson, pp. 357-394, John Wiley, Hoboken, N. J.

Wiele, S. M., J. B. Graf, and J. D. Smith (1996), Sand deposition in the Colorado River in the Grand Canyon from flooding of the Little Colorado River, Water Resour. Res., 32, 3579-3596.

Wiele, S. M., E. D. Andrews, and E. R. Griffin (1999), Effect of sand concentration on depositional rate, magnitude, and location, in The Controlled Flood in Grand Canyon, Geophys. Monogr. Ser., vol. 110, edited by R. H. Webb et al., pp. 131-145, AGU, Washington, D. C.

Wilson, R. T. (1986), Sonar patterns of Colorado River bed, Grand Canyon, in Proceedings of the Fourth Federal Interagency Sedimentation Conference, vol. 2, pp. 133-142, Subcomm. on Sedimentation of the Interagency Advis. Comm. on Water Data, Washington, D. C.

Wright, P., B. Goettlicher, and M. Pucherelli (2003), The development of a $97000 \mathrm{cfs}$ flow line within the Grand Canyon using geographic information system technology, Tech. Memo. 8260-03-04, Tech. Serv. Cent. Bur. of Reclamation, Denver, Colo.

P. E. Grams and P. R. Wilcock, Department of Geography and Environmental Engineering, Johns Hopkins University, Baltimore, MD 21218, USA.

S. M. Wiele, Water Resources Division, U.S. Geological Survey, 520 N. Park Ave., Suite 221, Tucson, AZ 85704, USA. 